Prepared in cooperation with the Bureau of Reclamation

\title{
Controls on Spatial and Temporal Variations of Brine Discharge to the Dolores River in the Paradox Valley, Colorado, 2016-18
}

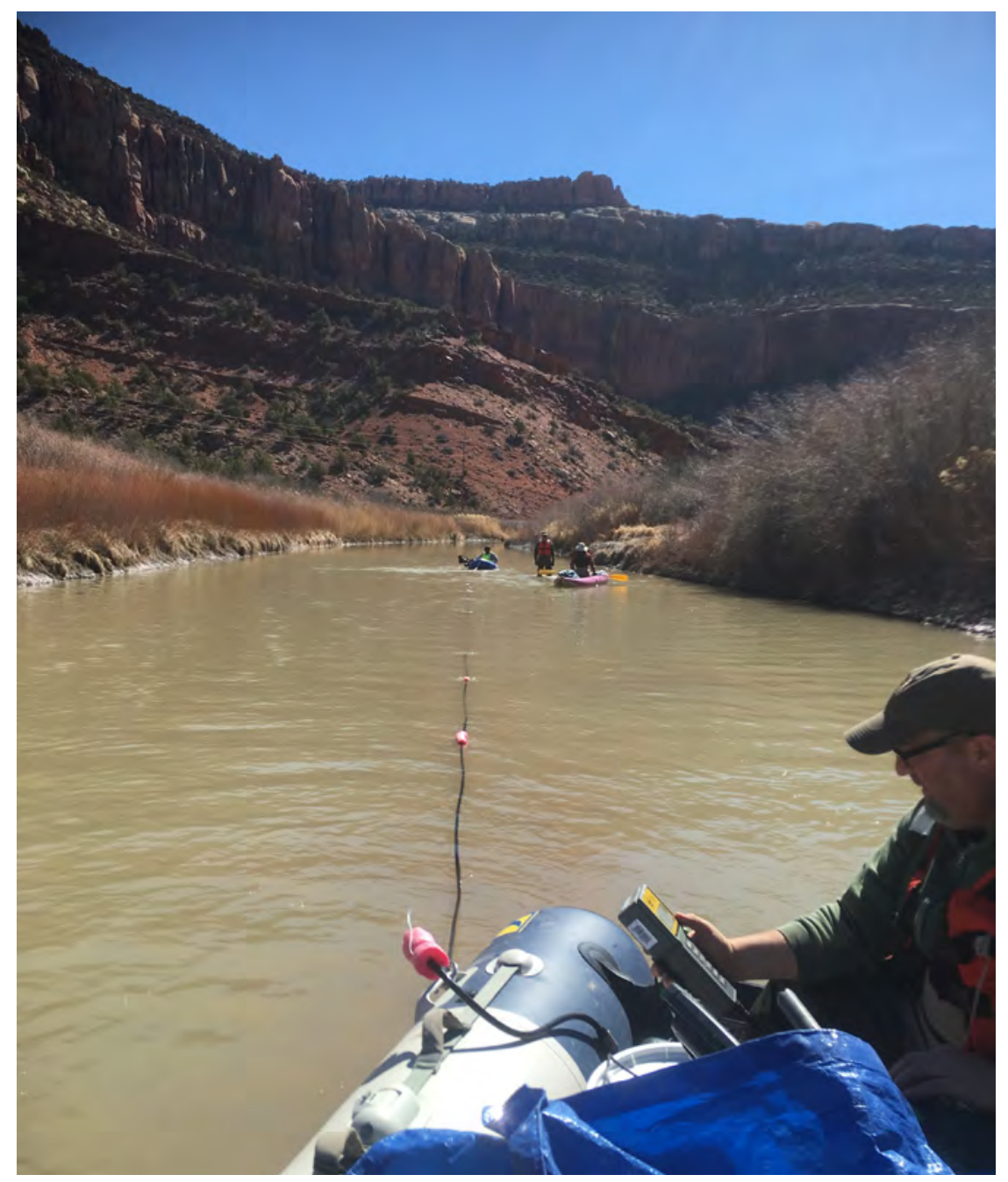

Scientific Investigations Report 2019-5058 
Cover. Floating electrode array used for continuous resistivity profiling in the Dolores River. (Photograph by U.S. Geological Survey) 


\section{Controls on Spatial and Temporal Variations of Brine Discharge to the Dolores River in the Paradox Valley, Colorado, 2016-18}

By M. Alisa Mast and Neil Terry

Prepared in cooperation with the Bureau of Reclamation

Scientific Investigation Report 2019-5058 


\title{
U.S. Department of the Interior DAVID BERNHARDT, Secretary
}

\author{
U.S. Geological Survey \\ James F. Reilly II, Director
}

U.S. Geological Survey, Reston, Virginia: 2019

For more information on the USGS - the Federal source for science about the Earth, its natural and living resources, natural hazards, and the environment-visit https://www.usgs.gov or call 1-888-ASK-USGS.

For an overview of USGS information products, including maps, imagery, and publications, visit https://store.usgs.gov.

Any use of trade, firm, or product names is for descriptive purposes only and does not imply endorsement by the U.S. Government.

Although this information product, for the most part, is in the public domain, it also may contain copyrighted materials as noted in the text. Permission to reproduce copyrighted items must be secured from the copyright owner.

Suggested citation:

Mast, M.A., and Terry, N., 2019, Controls on spatial and temporal variations of brine discharge to the Dolores River in the Paradox Valley, Colorado, 2016-18: U.S. Geological Survey Scientific Investigations Report 2019-5058, 25 p., https://doi.org/10.3133/sir20195058.

ISSN 2328-0328 (online) 


\section{Contents}

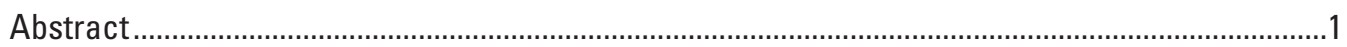

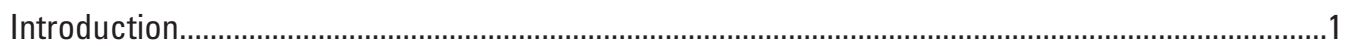

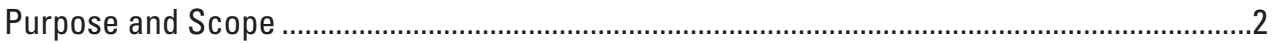

Study Area

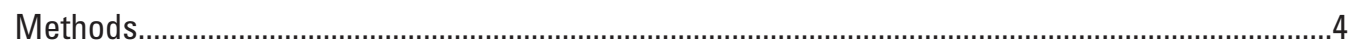

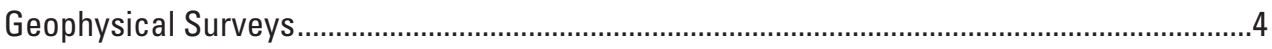

Electrical Resistivity Tomography ............................................................................

Continuous Resistivity Profiling .......................................................................................

Frequency Domain Electromagnetic Induction ...............................................................

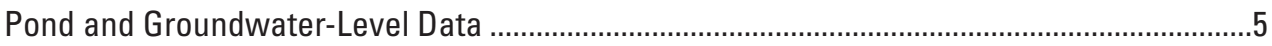

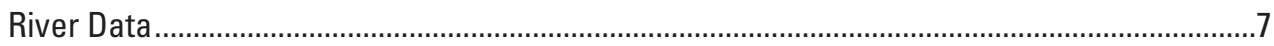

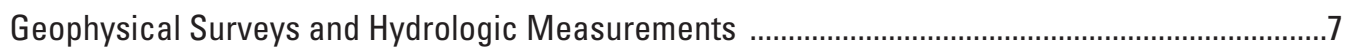

Geophysical Surveys ................................................................................................................

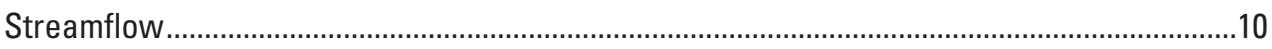

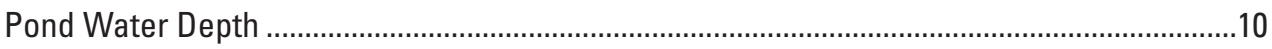

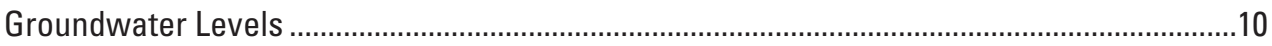

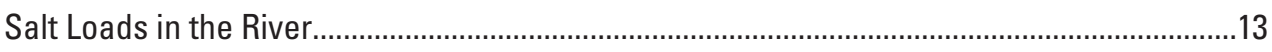

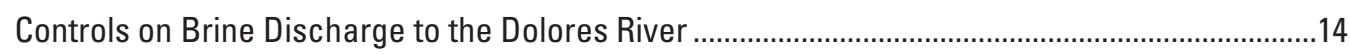

Spatial and Temporal Extent of Brine Interpreted from Geophysical Surveys........................14

Effect of Ponds on Salt Loading to the River ...................................................................16

Surface Water-Groundwater Interactions in Winter ........................................................19

Conceptual Model of Brine Discharge to the Dolores River .........................................................22

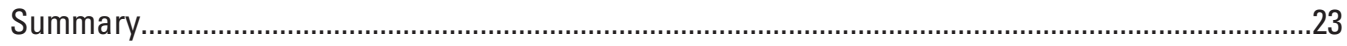

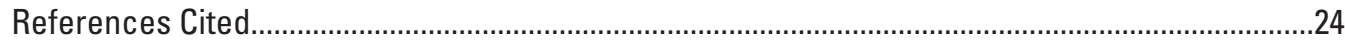

\section{Figures}

1. Map showing the Dolores River crossing the Paradox Valley, Colorado, and locations of monitoring sites, Paradox Valley Unit (PVU) production wells, electrical resistivity tomography (ERT) and frequency domain electromagnetic induction (FDEM) geophysical surveys, and river distance for river-based FDEM and continuous resistivity profiling (CRP) surveys

2. Locations of pond and groundwater monitoring sites, Paradox Valley Unit (PVU) production wells, and electrical resistivity tomography (ERT) surveys, Paradox Valley, Colorado

3. Graph showing specific conductance of the Dolores River in Paradox Valley, Colorado, measured during the three river-based frequency domain electromagnetic induction (FDEM) and continuous resistivity profiling (CRP) surveys in 2017

4. Inversion results for frequency domain electromagnetic induction data collected during the three river-based surveys of the Dolores River in Paradox Valley, Colorado, 2017: A, March 2017, B, May 2017, and C, September 2017.

5. Inversion results for continuous resistivity profiling data collected during three river-based surveys of the Dolores River in Paradox Valley, Colorado, 2017: 
6. Inversion results for electrical resistivity tomography (ERT) from the four surveys conducted in March 2017 with $A$, northernmost survey crossing the Dolores River (line a, electrode spacing $=2$ meters), $B$, survey parallel to river on the western river bank (line b, electrode spacing $=5$ meters) $C$, middle survey crossing the Dolores River (line c, electrode spacing $=2$ meters), and $D$, southernmost survey crossing the Dolores River (line d, electrode spacing $=5$ meters), Paradox Valley, Colorado

7. A, Streamflow for Dolores River near Bedrock (station 09171100); $B$, water depth in the wildlife ponds; $C$, depth to groundwater in upper and lower pond wells; and $D$, depth to groundwater in shallow and deep 3W3 wells, Paradox Valley, Colorado, during November 2016 through May 2018.

8. Daily total dissolved solids (TDS) load at two U.S. Geological Survey streamflow-gaging stations (stations 09169500 and 09171100) on the Dolores River and daily net salt gain to the river from the Paradox Valley, Colorado, October 2016 through May 2018

9. Interpolated depth slices of electrical conductivity (EC) from land- and river-based frequency domain electromagnetic induction (FDEM) inversions in 2017 and aerial electromagnetic (AEM) inversion results from Ball and others (2015): $A$, AEM EC depth slice centered at 1.5 meter below land surface, $B$, AEM EC depth slice centered at 5.0 meter below land surface, $C$, FDEM EC depth slice from 1.38 meter below land surface, and $D, F D E M E C$ depth slice from 5.17 meter below land surface..

10. River-based time lapse frequency domain electromagnetic induction surveys along the Dolores River, Paradox Valley, Colorado: $A$, profile of May minus March bulk electrical conductivity and $B$, profile of September minus March bulk electrical conductivity. Arrow indicates the low electrical conductivity anomaly at the bend in the river

11. Pond water depth and daily streamflow at Dolores River near Bedrock, Paradox Valley, Colorado (station 09171100), and daily net salt gain in the river during $A$, winter and spring 2017 and $B$, winter and spring 2018

12. Average daily net salt gain in winter months in the Dolores River, Paradox Valley, Colorado, before and after the establishment of wildlife ponds on the west side of the river

13. A, Monthly net salt gain and $B$, mean monthly streamflow at the Dolores River near Bedrock, Paradox Valley, Colorado (station 09171100), during water years (WY) 2017 and 2018.

14. Potentiometric surface for the alluvial aquifer on the west side of the Dolores River, Paradox Valley, Colorado, under $A$, high-flow conditions on May 9, 2017, and $B$, low-flow conditions on April 15, 2018.

15. Winter diurnal fluctuations in $A$, specific conductance and $B$, gage height of the Dolores River near Bedrock, Paradox Valley, Colorado (station 09171100), and $C$, air temperature at the lower pond during winter 2017-18

16. Daily salt load and mean daily gage height in the Dolores River near Bedrock, Paradox Valley, Colorado (station 09171100), for early winter 2018 (water year 2019). Vertical bars for stage represent daily minimum and maximum values (U.S. Geological Survey, 2019)

17. Net winter (November to March) salt gain in the Dolores River, Paradox Valley, Colorado, in relation to peak streamflow at Dolores near Bedrock (station 09171100) from the previous year's snowmelt for 1997-2015 


\section{Conversion Factors}

International System of Units to U.S. customary units

\begin{tabular}{|c|c|c|}
\hline Multiply & By & To obtain \\
\hline \multicolumn{3}{|c|}{ Length } \\
\hline meter $(\mathrm{m})$ & 3.281 & foot $(\mathrm{ft})$ \\
\hline kilometer (km) & 0.6214 & mile (mi) \\
\hline \multicolumn{3}{|c|}{ Area } \\
\hline square kilometer $\left(\mathrm{km}^{2}\right)$ & 0.3861 & square mile $\left(\mathrm{mi}^{2}\right)$ \\
\hline \multicolumn{3}{|c|}{ Flow rate } \\
\hline cubic meter per second $\left(\mathrm{m}^{3} / \mathrm{s}\right)$ & 35.31 & cubic foot per second $\left(\mathrm{ft}^{3} / \mathrm{s}\right)$ \\
\hline \multicolumn{3}{|c|}{ Mass } \\
\hline metric ton $(\mathrm{t})$ & 1.102 & ton, short $[2,000 \mathrm{lb}]$ \\
\hline \multicolumn{3}{|c|}{ Density } \\
\hline gram per cubic centimeter $\left(\mathrm{g} / \mathrm{cm}^{3}\right)$ & 62.4220 & pound per cubic foot $\left(\mathrm{lb} / \mathrm{ft}^{3}\right)$ \\
\hline
\end{tabular}

Temperature in degrees Celsius $\left({ }^{\circ} \mathrm{C}\right)$ may be converted to degrees Fahrenheit $\left({ }^{\circ} \mathrm{F}\right)$ as follows:

$$
{ }^{\circ} \mathrm{F}=\left(1.8 \times{ }^{\circ} \mathrm{C}\right)+32 .
$$

Temperature in degrees Fahrenheit $\left({ }^{\circ} \mathrm{F}\right)$ may be converted to degrees Celsius $\left({ }^{\circ} \mathrm{C}\right)$ as follows:

$$
{ }^{\circ} \mathrm{C}=\left({ }^{\circ} \mathrm{F}-32\right) / 1.8 \text {. }
$$

\section{Datum}

Vertical coordinate information is referenced to the North American Vertical Datum of 1988 (NAVD88).

Horizontal coordinate information is referenced to the North American Datum of 1983 (NAD83).

Elevation, as used in this report, refers to distance above the vertical datum (NAVD88).

\section{Supplemental Information}

Water year-0ctober 1 through September 30, designated by the year in which it ends.

Specific conductance is given in microsiemens per centimeter at 25 degrees Celsius $(\mu \mathrm{S} / \mathrm{cm})$.

Concentrations of total dissolved solids in water are given in milligrams per liter ( $\mathrm{mg} / \mathrm{L})$.

Streamflow is given in cubic feet per second $\left(\mathrm{ft}^{3} / \mathrm{s}\right)$. 


\section{Abbreviations}

$\begin{array}{ll}\text { AEM } & \text { airborne electromagnetic } \\ \text { CRP } & \text { continuous resistivity profiling } \\ \text { EC } & \text { bulk electrical conductivity in millisiemens per centimeter } \\ \text { ERT } & \text { electrical resistivity tomography } \\ \text { FDEM } & \text { frequency domain electromagnetic } \\ \text { km } & \text { kilometer } \\ \text { mg/L } & \text { milligrams per liter } \\ \text { NWIS } & \text { Nations Water Information System } \\ \text { ohm-m } & \text { ohm meter } \\ \text { PVU } & \text { Paradox Valley Unit } \\ \text { Reclamation } & \text { Bureau of Reclamation } \\ \text { SC } & \text { Specific conductance at 25 degrees Celsius } \\ \text { TDS } & \text { total dissolved solids } \\ \text { USGS } & \text { U.S. Geological Survey }\end{array}$




\title{
Controls on Spatial and Temporal Variations of Brine Discharge to the Dolores River in the Paradox Valley, Colorado, 2016-18
}

\author{
By M. Alisa Mast and Neil Terry
}

\section{Abstract}

The Paradox Valley in southwestern Colorado is a collapsed anticline formed by movement of the salt-rich Paradox Formation at the core of the anticline. The salinity of the Dolores River, a tributary of the Colorado River, increases substantially as it crosses the valley because of discharge of brine-rich groundwater derived from the underlying salts. Although the brine is naturally occurring, it increases the salinity of the Colorado River, which is a major concern to downstream agricultural, municipal, and industrial water users. The U.S. Geological Survey in cooperation with the Bureau of Reclamation conducted a study to improve the characterization of processes controlling spatial and temporal variations in brine discharge to the Dolores River. For the study, three geophysical surveys were conducted in March, May, and September 2017, and water levels were monitored in selected ponds and groundwater wells from November 2016 to May 2018. The study also utilized streamflow and specific conductance data from two U.S. Geological Survey streamflow-gaging stations on the Dolores River to estimate salt load to the river.

River-based continuous resistivity profiling and frequency domain electromagnetic induction surveys made during low-flow conditions indicated a zone of brine-rich groundwater close to the riverbed along an approximately 4-kilometer reach of the river. Under high-flow conditions, the brine was depressed as much as 2 meters below the riverbed, and brine discharge to the river was reduced to a minimum. Direct current electrical resistivity surveys show that the freshwater lens overlying the brine is much thicker (up to 10 meters) on the west bank than on the east bank (less than 5 meters). A large low-conductivity anomaly at river distance 6,800 meters was observed in all surveys and may represent a freshwater discharge zone or a losing reach of the river.

Filling and draining of the wildlife ponds on the west side of the river had a negligible effect on salt loads in the river during the study period. Groundwater monitoring showed there was active exchange of water between the river and the adjacent alluvial aquifer. When river stage was low, groundwater flowed towards the river, and brine discharge to the river increased. When the river stage was high, the gradient was reversed, and fresh surface water recharged the alluvial aquifer minimizing brine discharge. Most of the salt load to the river occurred during the winter and appeared to be enhanced by diurnal stage fluctuations.

A conceptual model of brine discharge to the river is presented at three scales. Groundwater at the regional scale drives dissolution of salt in the Paradox Formation and flow of brine into the base of the alluvial aquifer. Surface water-groundwater interactions at the scale of the alluvial aquifer control brine discharge to the river seasonally and interannually. At the finest scale, diurnal fluctuations in river stage drive exchange of freshwater with saltier pore water in the hyporheic zone, which appears to increase brine discharge to the river during winter.

\section{Introduction}

The Dolores River originates in the San Juan Mountains in southwestern Colorado and flows predominantly northwest before joining the Colorado River near the Colorado-Utah State line (fig. 1). Before reaching the confluence with the Colorado River, the Dolores River crosses the Paradox Valley, which is a structural and topographic basin trending northwest to southeast that was formed by a collapsed salt anticline (Cater, 1970). The core of the anticline contains the Paradox Formation, which consists of abundant evaporites largely composed of gypsum, anhydrite, and halite (Cater, 1970). The river crosses the Paradox Valley perpendicular to the valley trend, and near the center of the valley, the river flows across the axis of the anticline, where the salt-rich Paradox Formation is closest to the land surface (Bureau of Reclamation, 1978). In this area, concentrated sodium-chloride brine discharges into the river causing the specific conductance of the river to increase by $2-10$ times, depending on flow conditions (Mast, 2017). The brine is derived from salt in the Paradox Formation and is dissolved by groundwater that subsequently flows upward through overlying caprock into an alluvial aquifer to discharge into the river (Bureau of Reclamation, 1978).

Although the brine is naturally occurring, it substantially increases salinity of the Dolores River, which in turn contributes to the downstream salinity of the Colorado River. High salinity in the Colorado River is a major concern to agricultural, municipal, 
and industrial water users. The Colorado River Salinity Control Act, originally enacted in 1974 and later amended, authorizes the implementation of salinity-control projects throughout the basin to reduce salinity in the Colorado River (Bureau of Reclamation, 2018). One such project is the Paradox Valley Unit (PVU), which began operating in 1996 to reduce the salt load of the Dolores River (Bureau of Reclamation, 1978). The PVU, which is operated by the Bureau of Reclamation (Reclamation), is a series of nine production wells in the center of the Paradox Valley (fig. 1). The PVU production wells, which are adjacent to the river, withdraw brine from the base of the alluvial aquifer at a total rate of about 0.37 cubic foot per second $\left(\mathrm{ft}^{3} / \mathrm{s}\right)$. Withdrawal of brine by the production wells intercepts brine that might otherwise discharge into the river, thus reducing the salinity of the river before it exits the valley. The brine is disposed of by injection into the Leadville Formation through a 4,880-meter (m)-deep well near the western edge of the valley (fig. 1). A recent analysis concluded that the PVU facility has reduced the salt load in the Dolores River by an average of 89,600 tons ( 81,280 metric tons) per year since it began operation in 1996 (Mast, 2017). This amount of salt is about 10 percent of the total salinity control in the Colorado River, making the PVU one of the most effective salinity control projects in the Colorado River Basin (Bureau of Reclamation, 2018).

The U.S. Geological Survey (USGS), in cooperation with Reclamation, conducted a study from November 2016 to June 2018 to improve characterization of processes controlling spatial and temporal variations in brine discharge to the Dolores River as it flows across the Paradox Valley. This information may aid in making management decisions to evaluate alternative salinity-reduction strategies, such as water-management activities on the northwest side of the river or refinements in the pumping schedule for the production wells. Improved efficiency of the PVU is important considering that the existing brine injection well may be nearing the end of its useful life (Bureau of Reclamation, 2019). To further reduce salt loads to the river, Reclamation is considering expansion of the current well field to capture more brine. Although the PVU currently removes nearly 90,000 tons $(81,650$ metric tons) of salt annually, nearly 40,000 tons (36,290 metric tons) per year of salt is still exiting the valley in river flow (Mast, 2017), indicating substantial sources of brine are not captured by the current well field. More detailed information on the spatial extent of the brine plume may be useful for selecting optimum sites for new production wells.

\section{Purpose and Scope}

The purpose of this report is to present results of surface geophysical surveys conducted along the reach of the Dolores River where it crosses the Paradox Valley. Three surveys were conducted in 2017 under different hydrologic conditions to investigate controls on spatial and temporal variability in the extent of brine-rich groundwater under the Dolores River and to delineate potential areas of enhanced brine discharge to the river. Saline groundwater has a low electrical resistivity (high conductivity) compared to the river water and freshwater in the alluvial aquifer, which have high electrical resistivity (low conductivity). Thus, geophysical methods that measure electrical resistivity may be useful for identifying when and where brine discharge to the river is largest.

This report also presents water-level data for two ponds and three groundwater wells on the west side of the Dolores River collected from November 2016 through May 2018. These data were compared to changes in total dissolved solids (TDS) concentrations and loads in the Dolores River at Bedrock site (station 09169500) and the Dolores River near Bedrock site (station 09171100) to evaluate how pond and wetland management affects brine discharge to the river.

\section{Study Area}

The study area is in the Paradox Valley, which is a northwest-southeast trending structural and topographic basin approximately 40 kilometers $(\mathrm{km})$ long and $4-8 \mathrm{~km}$ wide in western Colorado (fig. 1). Climate on the valley floor is semiarid, and mean annual precipitation is about 30 centimeters $(\mathrm{cm})$ per year (https://wrcc.dri.edu/Climate/summaries.php, accessed December 2018). The Dolores River originates in the San Juan Mountains southeast of the study area and drains a 5,242-square-kilometer $\left(\mathrm{km}^{2}\right)$ area upstream from the Paradox Valley. Upon entering the southwest side of the valley, the Dolores River flows along $11 \mathrm{~km}$ of river channel crossing the valley floor from southwest to northeast perpendicular to the main trend of the valley (fig. 1). Streamflow in the Dolores River is largely derived from snowmelt runoff at higher elevations. However, flow through the Paradox Valley is regulated by releases from McPhee Reservoir, which is approximately $145 \mathrm{~km}$ upstream from the valley. West Paradox Creek is the only perennial tributary in the valley and is used to deliver irrigation water from Buckeye Reservoir, which is $19 \mathrm{~km}$ northwest of the river. Buckeye Reservoir stores water derived from snowmelt runoff in the La Sal Mountains, which border the northwest end of the valley. Major land uses in the valley include rangeland and about $11 \mathrm{~km}^{2}$ of irrigated cropland and pasture northwest of the river (fig. 1). Surface water diverted from West Paradox Creek and the Dolores River are the primary sources of irrigation water.

Shallow fresh groundwater in the Paradox Valley is mainly limited to Quaternary alluvial deposits along the Dolores River (fig. 1) and in the northwestern end of the valley along West Paradox Creek. Alluvial deposits along the river are composed of layers of sand, gravel, and clay with a total thickness of up to 51 meters (m) (Bureau of Reclamation, 1978). The principal sources of recharge to the alluvial aquifer are lateral flow from the Dolores River and West Paradox Creek, infiltration of excess applied irrigation water, leakage from irrigation canals and ponds, and precipitation. Near the center of the valley, brine derived from the top of the Paradox Formation upwells through a caprock at the top of the salt into the base of the alluvial aquifer (Bureau of Reclamation, 1978). The caprock is a collapsed residuum consisting of anhydrite, dolomite, and shale that ranges from 120 to $150 \mathrm{~m}$ in thickness (Bureau of Reclamation, 1978). Near the river, the caprock is thinnest and has 

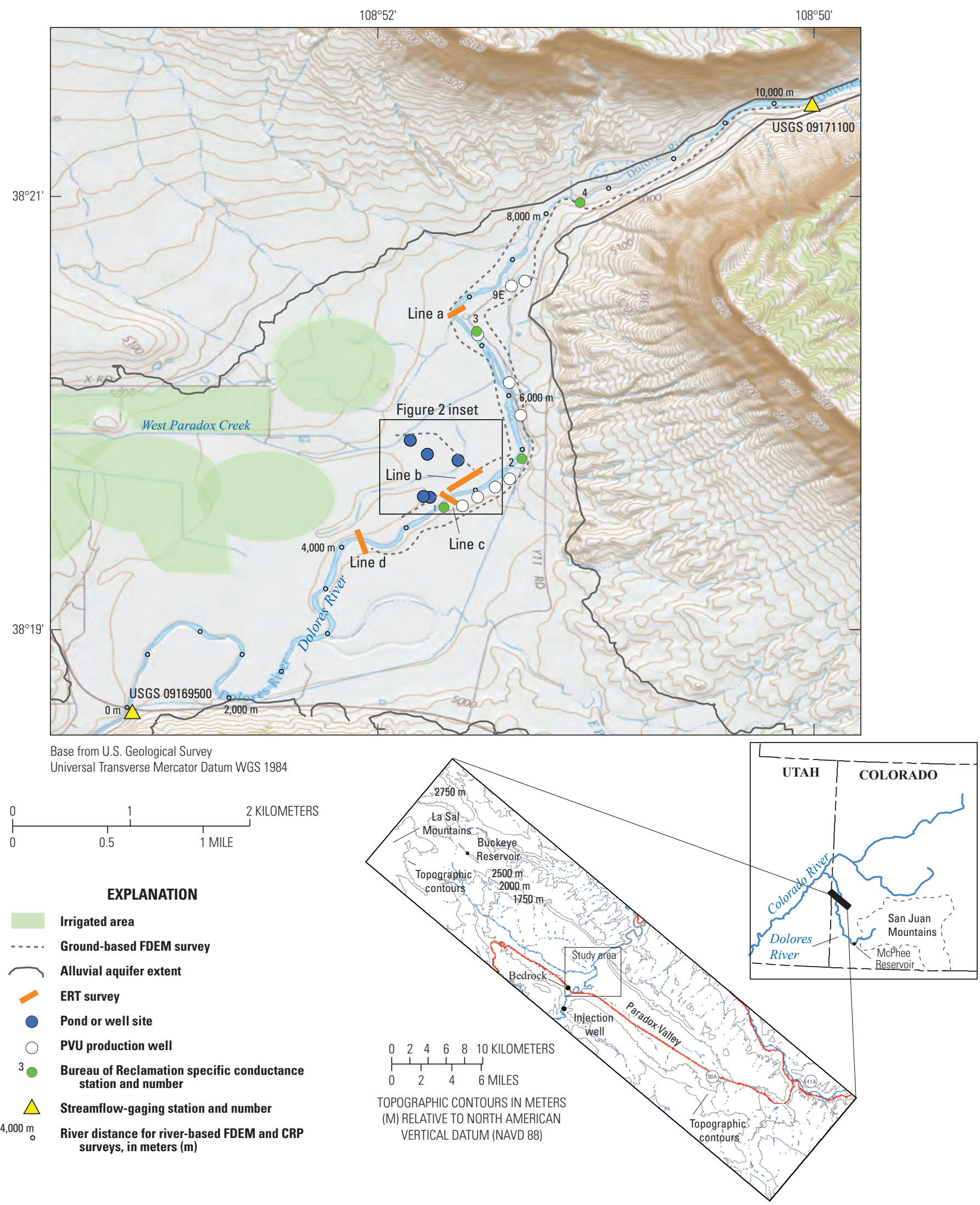

Figure 1. Dolores River crossing the Paradox Valley, Colorado, and locations of monitoring sites, Paradox Valley Unit (PVU) production wells, electrical resistivity tomography (ERT) and frequency domain electromagnetic induction (FDEM) geophysical surveys, and river distance for river-based FDEM and continuous resistivity profiling (CRP) surveys. 
been brecciated, possibly increasing the hydraulic conductance through the caprock near the river (Bureau of Reclamation, 1978). Salt-saturated groundwater flowing upward through the caprock mixes with freshwater to produce brine at the base of the alluvial aquifer. Because the brine has a density of nearly 1.2 grams per cubic centimeter, water in the alluvial aquifer is stratified, containing a dense brine layer overlain by freshwater from nearby surficial recharge (Bureau of Reclamation, 1978). The mixing zone between the brine and freshwater is thought to be relatively thin and is often referred to as the freshwaterbrine interface. The interface is deeper on the west side of the river where the freshwater layer is thicker because of a greater abundance of freshwater that recharges from West Paradox Creek and irrigation return flows (Konikow and Bedinger, 1978). The interface is shallow or nonexistent on the east side of the river because alluvial deposits are thinner and there is no irrigation (Konikow and Bedinger, 1978). Salt concentrations in the brine below the freshwater-brine interface have been measured to be as large as 250,000 milligrams per liter (mg/L) (Watts, 2000). In some reaches, the freshwater-brine interface converges towards the riverbed and brine discharges into the Dolores River (Watts, 2000).

\section{Methods}

This section describes methods for geophysical surveys, water-level monitoring at ponds and groundwater wells on the northwest side of the river, and continuous monitoring at two USGS streamflow-gaging stations on the Dolores River (stations 09169500 and 09171100). Geophysical surveys were conducted during three trips in 2017 to coincide with low-flow conditions in March, high-flow conditions in May, and low-flow conditions in September. Water-level instrumentation was installed on November 16, 2016, and data were collected through June 9, 2018. Monitoring at the USGS streamflow-gaging stations began in 1971 and is ongoing.

\section{Geophysical Surveys}

Three types of geophysical data were collected for this study: direct current electrical resistivity tomography (ERT), continuous resistivity profiling (CRP), and frequency domain electromagnetic induction (FDEM). Each of these tools was used to estimate the bulk electrical conductivity (EC) of earth materials as a proxy for groundwater salinity. The ERT surveys were conducted via statically positioned electrodes installed directly into the ground or riverbed, or both. The CRP surveys used boat-towed electrodes that floated on top of the river, and the FDEM surveys employed a non-contact electromagnetic induction sensor that was either hand carried, boat carried, or vehicle towed slightly elevated above the land or water surface. Each of the methods is described in further detail in the following sections. The raw geophysical and ancillary data from the surveys are available in a companion USGS data release (Mast and others, 2019).

\section{Electrical Resistivity Tomography}

The ERT method involves a series of direct-current injections via electrodes implanted into the ground. Electrical potential is measured at other electrodes, which are often arranged in a line with fixed spacing between them. The measured electrical potential is a function of the magnitude of the injected current, the positioning of the electrodes, and the resistivity of the earth materials. Although ERT measurements do not provide a complete picture of earth resistivity, inverse methods can be used to reconstruct approximate earth resistivity (the inverse of the bulk electrical conductivity (EC) in millisiemens per centimeter, or 1/EC) models within the area of the survey. For additional details on this method, see Binley (2015).

During March 6-10, 2017, ERT surveys were conducted along three lines across the river using a waterproof cable and electrodes implanted directly into the riverbed and one line parallel to the river (fig. 1) using an Advanced Geosciences SuperSting R8 resistivity system (AGI, 2019). For each of these surveys, fifty-six 50 -cm long steel electrodes were installed into the shallow subsurface and riverbed at either $2 \mathrm{~m}$ or $5 \mathrm{~m}$ spacing, and measurements were made using two different electrode configurations: Schlumberger-Wenner and dipole-dipole.

Data were filtered out that had large stacking errors (greater than 2-percent difference based on two repeat measurements) and apparent resistivities outside the range of $0.1-1,000 \mathrm{ohm}$ meters (ohm-m) (more than 99 percent of the dataset was retained after filtering). Although contact resistance checks in the field indicated less than 5,000 ohms resistances across all electrode pairs, analysis of data errors associated with a few electrodes indicated abnormally large errors associated with these electrodes in different surveys. All measurements associated with these problematic electrodes were removed.

The ERT inversions were performed using the software program R2 (Lancaster University, 2019), assuming a 5-percent error model. Depths of investigation (Oldenburg and Li, 1999) were calculated in R2 for each ERT survey using 1- and 5-ohm-m homogeneous background models and background regularization $\left(\alpha_{s}\right)$ of 10 (unitless).

\section{Continuous Resistivity Profiling}

The CRP method is essentially a mobile, waterborne deployment of ERT. Electrodes directly contact the water as they are towed behind a boat. Given that data are collected in a mobile fashion, CRP surveys are typically designed to measure electrical potential from one current injection at several potential electrodes at once using multichannel resistivity systems (Day-Lewis and others, 2006).

The CRP data were collected along an 8- to $10-\mathrm{km}$ reach of the Dolores River between the USGS streamflow-gaging stations on March 7, May 16, and September 13, 2017 (river distance corresponding to CRP surveys shown in fig. 1). Data were collected using an Advanced Geosciences, Inc. (AGI, Austin, Texas) SuperSting R8 Marine resistivity system configured with a floating, multi-electrode cable pulled by a 
raft. The electrode cable used 11 electrodes spaced $3 \mathrm{~m}$ apart. A dipole-dipole configuration was used for the CRP data collection in which two fixed-current electrodes were energized (the two electrodes closest to the raft), and voltages were then measured between electrode pairs in the remaining nine electrodes. The resistivity meter used an external global positioning system and echosounder to determine the spatial location of the array and the depth of the water column. A separate YSI 85 conductivity and temperature sensor (YSI, 2019) was also deployed in the water during data collection to monitor river specific conductance. Data collected with each CRP survey included latitude, longitude, injected current, voltage, resistance, apparent resistivity, electrode location (referenced to the position of the global positioning system), river depth, water temperature, and specific conductance.

After preliminary formatting and filtering steps, including removing data having replicate measurement (stacking) errors of greater than 2 percent, removing data with unrealistic apparent resistivity (less than 0 or greater than 10,000 ohm-m), and removing data collected while the boat was stationary, the CRP data were processed and inverted using Aarhus Workbench software (Aarhus GeoSoftware, 2019) and the streamed ERT module. Eight voltage potentials were measured for each current injection; therefore, for each horizontal position along the river, there were 8 associated data points. These data were imported into the software, assuming 10-percent data errors, and were reconfigured to $10-\mathrm{m}$ intervals using a 3-m moving window. A smooth, laterally constrained inversion was performed wherein EC was estimated at 10 log-spaced layers going from the ground surface to a $20-\mathrm{m}$ depth at each spatial location. This type of inversion is an attempt to fit one-dimensional electrical conductivity models to data while penalizing models that deviate vertically and laterally. For more information on the inverse algorithm used, see Auken and others (2015). Depth of investigation calculations were also performed during the inversion (Christiansen and Auken, 2012).

\section{Frequency Domain Electromagnetic Induction}

The FDEM methods induce electromagnetic fields in earth materials by generating current in a wire loop at a specified frequency or suite of frequencies. Conductive materials within the earth then generate secondary fields that are measured by a receiver at the surface (Frischknecht and others, 1991). Because direct ground contact is not required for FDEM, systems are typically designed so that data can be collected at walking speed.

The FDEM surveys were made using a portable GEM-2 instrument (Geophex Ltd., 2019) along the same paths as the CRP and ERT surveys. Additional FDEM data were collected by walking or driving the GEM-2 on land (fig. 1). Multi-frequency $(\mathrm{n}=7)$ quadrature data ranging from 1,530 to 47,970 hertz were recorded in horizontal coplanar mode to estimate subsurface electrical conductivity.
The FDEM data were processed and inverted using Aarhus Workbench software (Aarhus GeoSoftware, 2019) and the ground conductivity meter module. Data for the seven frequencies were imported into the software, assuming a 10 -percent error, and were reconfigured to 1 -m intervals using a 3-m moving window. Waterborne data were assigned an instrument elevation of $0.3 \mathrm{~m}$, and land-based data were assigned an instrument elevation of $1.0 \mathrm{~m}$. A smooth, laterally constrained inversion was performed wherein electrical conductivity was estimated at $20 \mathrm{log}$-spaced layers going from the ground surface to a $15-\mathrm{m}$ depth at each spatial location. Depth of investigation calculations that estimate the approximate reliable depth of sensitivity for inversion results were calculated within the software during the inversion.

\section{Pond and Groundwater-Level Data}

Two shallow ponds (less than 1-m deep) on the west side of the river, the lower pond site (station 381937108514701) and the upper pond site (station 381952108515101), were selected for water-level monitoring installations (fig. 2). These ponds were constructed by the Fish and Wildlife Service in 2003 to improve wildlife habitat and are filled seasonally by land owners with water diverted from West Paradox Creek (Andrew Nicholas, Bureau of Reclamation, written commun., 2018). A $1.5-\mathrm{m}$ vertical plastic pipe, anchored to a fence post, was installed in the center of each pond. An Onset non-vented water-level sensor was deployed on a cable inside the pipe to $2.5 \mathrm{~cm}$ above the bottom of the pond. A second water-level sensor was attached to the top of the pipe at the lower pond site to record air temperature and barometric pressure.

Two shallow groundwater wells, the lower pond well (station 381937108514601) and the upper pond well (station 381947108514701), were installed downgradient from each pond into the sandy sediments of the alluvial aquifer (fig. 2). The wells were hand bored to a depth of about $1.2 \mathrm{~m}$ using a soil auger. A 5-cm diameter steel well point was hand driven into the hole to a maximum depth of about $2 \mathrm{~m}$. The well point had a 7.6-cm long metal tip at the end of a $90-\mathrm{cm}$ section of screened steel pipe. Steel riser pipe was added to the well point to extend the pipe above the ground surface. An Onset water-level sensor was deployed on a cable inside of the pipe to within $2 \mathrm{~cm}$ of the bottom of the well.

An observation well installed by Reclamation in the 1970s (well 3W3) was instrumented as part of this study (fig. 2). The borehole was drilled to a depth of more than $60 \mathrm{~m}$ and contained two wells completed at different depths, $3 \mathrm{~W} 3$ shallow well (station 381947108513801) and 3W3 deep well (station 381947108513802). The shallow well is $24 \mathrm{~m}$ deep and is completed near the base of the alluvial aquifer with a screened interval of $1.5 \mathrm{~m}$ at the bottom of the well casing (Bureau of Reclamation, 1978). The deep well is $66 \mathrm{~m}$ deep and is completed in the gypsum breccia at the top of the Paradox Formation with a screened interval of $1.5 \mathrm{~m}$ at the bottom of the well casing (Bureau of Reclamation, 1978). For this study, 
the depth of each well was confirmed, although no attempt was made to verify the screened interval or connectivity to the aquifer. The wells were each instrumented with a Global Water level logger WL16, which is a vented submersible pressure transducer. The stainless-steel sensor was deployed to a depth of about $2 \mathrm{~m}$ below the water-level surface, and the logger was attached to the outside of the well pipe.

Sensor measurements (depth of water above the sensor, temperature, and barometric pressure) at the ponds and wells were electronically recorded by data loggers every 2 hours from November 2016 to June 2018. Quarterly site visits were made to download the data loggers and make manual waterlevel measurements. A measuring point was established at each well casing and pond pipe as a consistent point from which to make measurements. The height of each measuring point above the land surface was manually measured. The elevation of each measuring point was determined using a real-time kinematic global navigation satellite system, following the methods described in Rydlund and Densmore (2012). Water levels in the wells were measured using an electric tape, according to methods in Cunningham and Schalk (2011). The water-level elevation was determined by subtracting the measured depth to water below land surface from the landsurface elevation above North American Vertical Datum of 1988 at each well location. The pond depth was determined by measuring the depth of the pond surface below the measuring point, which was subtracted from the height of the measuring point above the land surface. The Hoboware software program (Onset, 2019) was used to correct the Onset sensor readings for barometric pressure. The corrected sensor data for the ponds and wells were uploaded into the USGS National Water Information System (NWIS) at https://dx.doi.org/10.5066/ F7P55KJN and processed following guidelines in Freeman and others (2004).

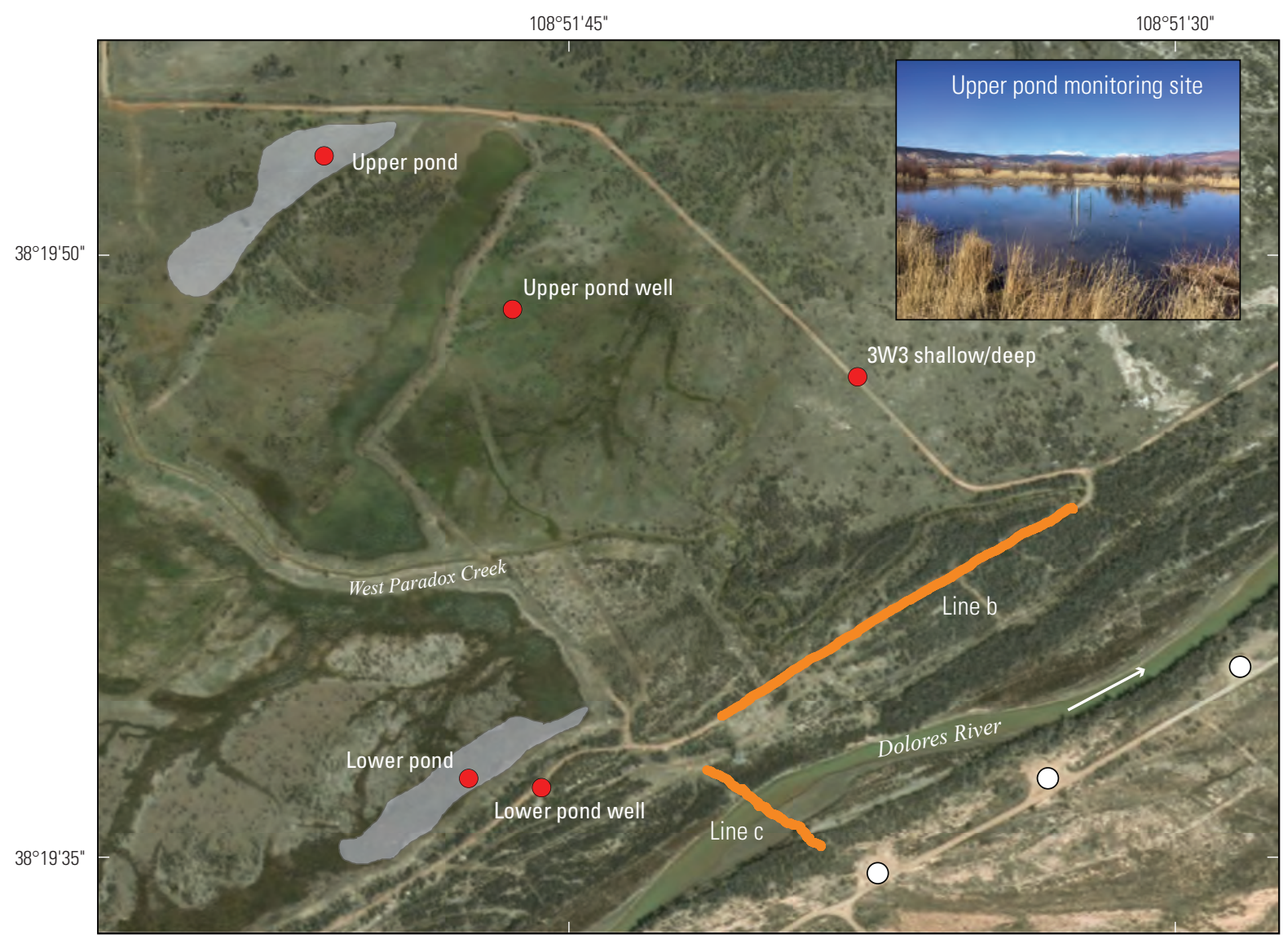

Base from U.S. Geological Survey

Universal Transverse Mercator Datum WGS 1984

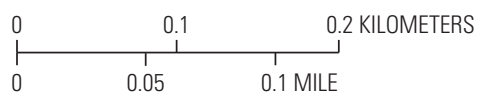

\section{EXPLANATION}

Approximate pond area

ERT survey
Instrumented pond or well

$\bigcirc$ PVU production well

Figure 2. Locations of pond and groundwater monitoring sites, Paradox Valley Unit (PVU) production wells, and electrical resistivity tomography (ERT) surveys, Paradox Valley, Colorado. 


\section{River Data}

Continuous (15-minute) streamflow and specific conductance at 25 degrees Celsius (SC) were measured by the USGS at two sites on the river: the Dolores River at Bedrock (station 09169500), herein referred to as the "upstream site," and the Dolores River near Bedrock (station 09171100), herein referred to as the "downstream site" (fig. 1). A summary of site history and data collection methods is given in Mast (2017), and daily- and unit-value streamflow and SC data are available from the NWIS database at https://dx.doi.org/10.5066/F7P55KJN. This study utilized historical (Mast, 2017) and recent data (October 2016 to May 2018) from the two stations. Data gaps were filled using methods described by Mast (2017) to obtain a complete record of daily mean streamflow and SC for the study period. Daily mean total dissolved solids (TDS) concentrations were computed from daily mean SC for each streamflow-gaging station using the relation

$$
\mathrm{TDS}=0.526 \times \mathrm{SC}+0.00000113 \times \mathrm{SC}^{2}
$$

where

$$
\begin{gathered}
\text { TDS total dissolved solids, in milligrams per liter } \\
\text { (mg/L) and } \\
\text { SC is specific conductance, in microsiemens per } \\
\text { centimeter at } 25 \text { degrees Celsius }(\mu \mathrm{S} / \mathrm{cm}) \\
\text { (Mast, 2017). }
\end{gathered}
$$

Daily TDS load (daily salt load) in tons per day was computed by multiplying the streamflow in cubic feet per second $\left(\mathrm{ft}^{3} / \mathrm{s}\right)$ by the TDS concentration in milligrams per liter with a conversion factor of 0.0026969 . Daily net salt gain to the river as it crosses the Paradox Valley was computed from the daily TDS load at the downstream site minus the load at the upstream site. As used in this report, one ton is equal to 907 kilograms or 0.907 metric tons. Details of the computation methods can be found in Mast (2017).

\section{Geophysical Surveys and Hydrologic Measurements}

This section presents results of geophysical surveys conducted on three dates in 2017. Results of streamflow monitoring and water-level monitoring at the ponds and groundwater wells during the study period also are presented. Daily salt loads at the two streamflow-gaging stations are presented with net salt gain to the river in tons per day as the Dolores River crosses the Paradox Valley.

\section{Geophysical Surveys}

River-based FDEM and CRP surveys were made on three dates in 2017 (March, May, and September), representing different seasons and hydrologic conditions. Mean daily streamflow was $53 \mathrm{ft}^{3} / \mathrm{s}$ during the March survey, $895 \mathrm{ft}^{3} / \mathrm{s}$ during the May survey, and $64 \mathrm{ft}^{3} / \mathrm{s}$ during the September survey. Geophysical surveys in March and September started near the upstream USGS streamflow-gaging station (0 meters) and ran a linear distance of approximately 10,000 $\mathrm{m}$ across the valley floor ending near the downstream USGS streamflow-gaging station (fig. 1). The May survey measurements started approximately 4,200 $\mathrm{m}$ farther downstream because bridge construction closed access to the upstream boat launch. Specific conductance of the river during each of the three river-based surveys (fig. 3 ) is plotted as a function of distance along the river. In the March and September surveys, SC of the river began to increase at a river distance of about 4,000 $\mathrm{m}$ and continued to increase downstream to about 8,000 $\mathrm{m}$, beyond which it stabilized. In May, SC was the lowest (approximately $400 \mu \mathrm{S} / \mathrm{cm}$ ) of the three surveys and exhibited little change along the length of the river. Specific conductance of the river overall was greater in March (beginning at approximately $700 \mu \mathrm{S} / \mathrm{cm}$ and ending at $2,800 \mu \mathrm{S} / \mathrm{cm}$ ) than in September (ranging from $500 \mu \mathrm{S} / \mathrm{cm}$ to $1,200 \mu \mathrm{S} / \mathrm{cm}$ ).

Results of the FDEM and CRP inversions for the river-based surveys are shown in figures 4 and 5, respectively. Each individual image is a cross section of EC with depth below the water surface along the length of the river (linear distance downstream from station 09169500). Although EC variations may be caused by changes in subsurface lithology, the relatively uniform composition of the alluvial aquifer and the high salinity of groundwater in the Paradox Valley indicate that EC variations measured in this study primarily result from variations in groundwater salinity. The color scale in each image ranges from blues to reds, with blues representing fresher water and reds representing more saline water. The conductivity scales are the same for each image to facilitate comparison among the surveys. Areas below the computed depth of investigation are shown as semi-transparent in the two figures.

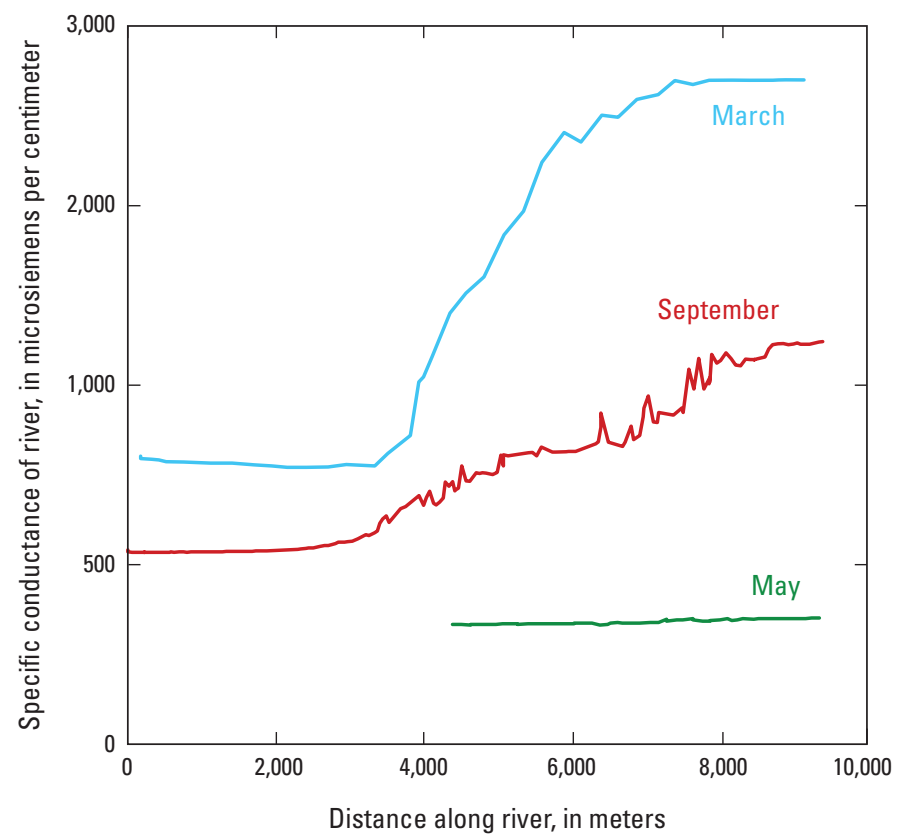

Figure 3. Specific conductance of the Dolores River in Paradox Valley, Colorado, measured during the three river-based frequency domain electromagnetic induction (FDEM) and continuous resistivity profiling (CRP) surveys in 2017. Distance along the Dolores River from figure 1. 

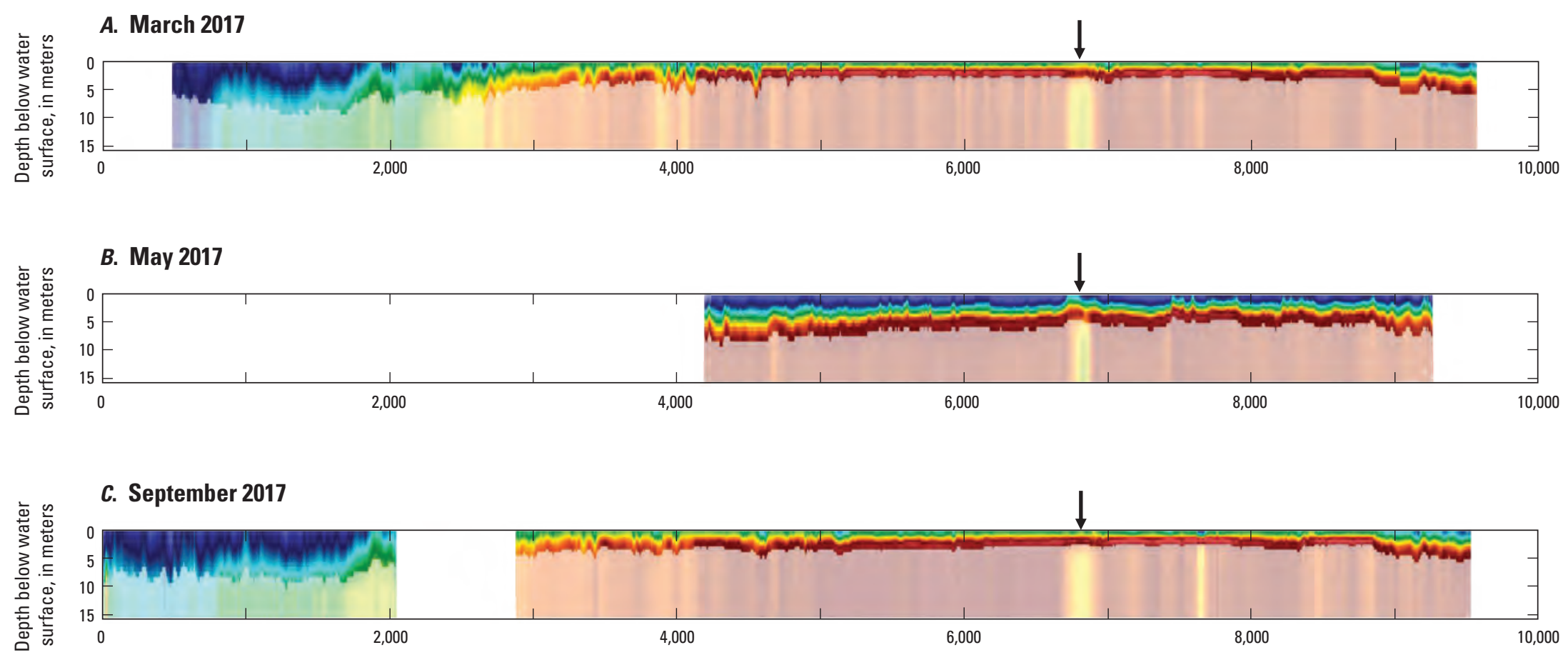

Distance along Dolores River, in meters

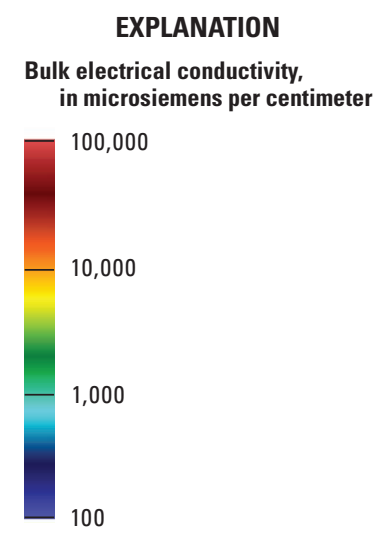

Figure 4. Inversion results for frequency domain electromagnetic induction data collected during the three river-based surveys of the Dolores River in Paradox Valley, Colorado, 2017: A, March 2017, B, May 2017, and C, September 2017. Areas below the computed depth of investigation are semi-transparent. Arrow indicates a low electrical conductivity anomaly. Distance along the Dolores River from figure 1. 

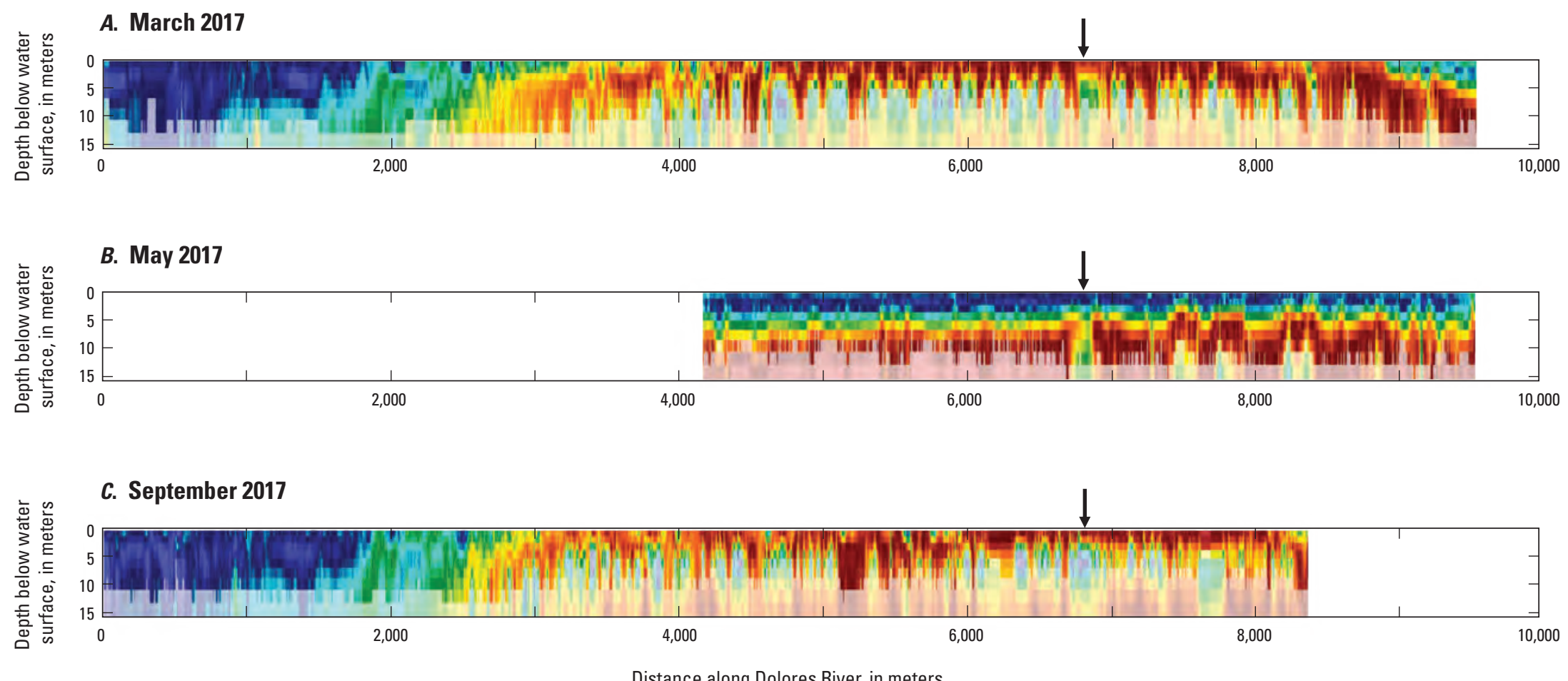

Distance along Dolores River, in meters

EXPLANATION
Bulk electrical conductivity,
in microsiemens per centimeter
100,000
10,000
1,000
100

Figure 5. Inversion results for continuous resistivity profiling data collected during three river-based surveys of the Dolores River in Paradox Valley, Colorado, 2017: A, March 2017, B, May 2017, and C, September 2017. Areas below the computed depth of investigation are semi-transparent. Arrow indicates a low electrical conductivity anomaly. Distance along the Dolores River from figure 1. 
The CRP inversions appear to show more variability than the FDEM perhaps in part because of positional differences in the electrodes, although many subsurface features (for example the high and low EC anomalies from 4,000 to 8,000 linear meters) appear consistently in the two low-flow surveys (March and September; fig. $4 A, C$ and fig. $5 A, C$ ) for both methods. Results from CRP and FDEM show similar patterns, though CRP results indicate a deeper depth of investigation (typically about $8 \mathrm{~m}$ ) compared to the FDEM (typically about $4 \mathrm{~m}$ ). In both datasets, March and September data show a low EC region (less than $1,000 \mu \mathrm{S} / \mathrm{cm}$ ) from about 0 to 2,000 linear meters along the Dolores River, likely indicating less conductive groundwater in the upper reach of the river. From about 2,000 to 4,000 m, high salinity groundwater or brine (greater than $10,000 \mu \mathrm{S} / \mathrm{cm}$ ) is seen to gradually rise towards the surface within the sediments below the river. Rising specific conductance is recorded in the river downstream from this point (fig. 3) where the brine appears to be at the riverbed (fig. $4 A, C$; fig. $5 A, C$ ). Continued increases in specific conductance were observed in the river to a distance of 8,000 meters, after which the specific conductance readings stabilized (fig. 3). At around 9,000 m, the high brine again begins to decrease in elevation (fig. $4 A, C$; fig. $5 A, C$ ). These dynamics are not observed during high flow (May 2017) where results indicate relatively low and stable river specific conductance (fig. 3) and a thicker (approximately $5 \mathrm{~m}$ ) low-conductivity groundwater (freshwater) zone in the 4,000 to $8,000 \mathrm{~m}$ reach (fig. $4 B$, fig. $5 B$ ).

Inversions of the ERT surveys made during March 6-10, 2017 are shown in figure 6. Each individual image is a cross section of EC with depth below the riverbed or land surface for three lines crossing the river and one line parallel to it (fig. 1). The color scheme and scale are the same as those used for the FDEM and CRP inversions (figs. 4 and 5). Results show the most conductive material directly under the river in all three river cross sections, although this high EC groundwater is most prevalent in the middle section (fig. $6 C$ ). The area of high EC appears to be asymmetrical with less conductive groundwater (less than $1,000 \mu \mathrm{S} / \mathrm{cm}$ ) in the upper $10 \mathrm{~m}$ on the west side of the river and more conductive groundwater on the east side of the river (fig. $6 C-D$ ). The line parallel to the west side of the river shows a uniform layer of low EC material up to 10 $\mathrm{m}$ in thickness that presumably overlies high EC groundwater, which is beneath the computed depth of investigation (fig. 6B).

\section{Streamflow}

Flows in the Dolores River during water year 2017 (October 2016-September 2017) were the greatest in more than a decade because of an above average snowpack and cool, wet spring weather that delayed the start of snowmelt. During 2017, releases from McPhee Reservoir started in mid-March and lasted through the end of June (Colorado Division of Water Resources, 2019). A peak flow of 3,530 $\mathrm{ft}^{3} / \mathrm{s}$ at the downstream site occurred on May 5, 2017, followed by a second peak of 1,660 ft $3 / \mathrm{s}$ on June 12, 2017 (fig. 7). Several rain events caused brief periods of elevated flows in July and August. Streamflow during fall and winter, which ranged from 40 to $60 \mathrm{ft}^{3} / \mathrm{s}$, are mainly controlled by releases from McPhee Reservoir to maintain downstream fisheries. In sharp contrast to the previous year, 2018 had one of the driest winters on record with precipitation less than 50 percent of average for southwestern Colorado (National Resources Conservation Service, 2019). Because of dry conditions, mean daily streamflow at the downstream site did not exceed $70 \mathrm{ft}^{3} / \mathrm{s}$ during May 2018; in the previous year, the streamflow in May was more than $3,500 \mathrm{ft}^{3} / \mathrm{s}$ (fig. $7 A$ ).

\section{Pond Water Depth}

The wildlife ponds were full or filling in November 2016 when instrumentation was installed and remained full until late February 2017 when the water depth in the ponds started to decline (fig. $7 B$ ). The small variations in water level through the winter were caused by ice formation at the surface of the pond during cold periods. The first increase in streamflow in March (peak on March 20) caused the pond levels to rise by about $0.06 \mathrm{~m}$. Immediately following the peak, pond levels declined rapidly, presumably because pond inflows were diverted elsewhere. The upper pond was dry by April 3, 2017, and remained dry through the summer, whereas the lower pond, which is less than $100 \mathrm{~m}$ from the river, first dried out on April 8 but had 1-2 weeks of standing water in May and again in June, coinciding with periods of increased streamflow (fig. $7 A$ ). The upper pond began to fill again in early November 2017 and remained full through the second winter with a brief dip in early January 2018. The lower pond did not fill until January 2018 , and the maximum depth was 30 percent less than it had been the previous winter. In 2018, waters levels began to drop in early March, and both ponds were dry by March 3, nearly 3 weeks earlier than in the spring of 2017. The earlier date of water loss and the shallower depth of the lower pond in 2018 indicate less water may have been available in West Paradox Creek because of dry conditions and less snowfall during the second year of the study.

\section{Groundwater Levels}

Groundwater levels in the shallow wells stayed relatively constant through the winter of 2017 when the ponds were full (fig. 7C). Shallow depths to groundwater in winter may be the result of recharge from West Paradox Creek, lower rates of evapotranspiration, and lack of irrigation. Groundwater levels began to gradually decline (increasing depth to groundwater) around the time the ponds dried up and were near their lowest levels (largest depth to groundwater) by early August 2017. Groundwater levels in both wells responded to increased flows in the river, most notably the streamflow peaks on May 5 and June 12, 2017 (fig. 7A). The rise in groundwater level (decreasing depth to groundwater), in response to the river, was as much as $1 \mathrm{~m}$ greater at the lower pond well. The lower 


\section{A. Dolores River}

West

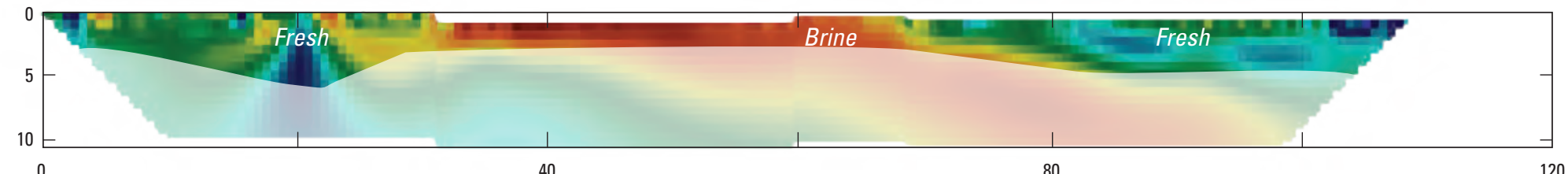

\section{B. Dolores River}

West
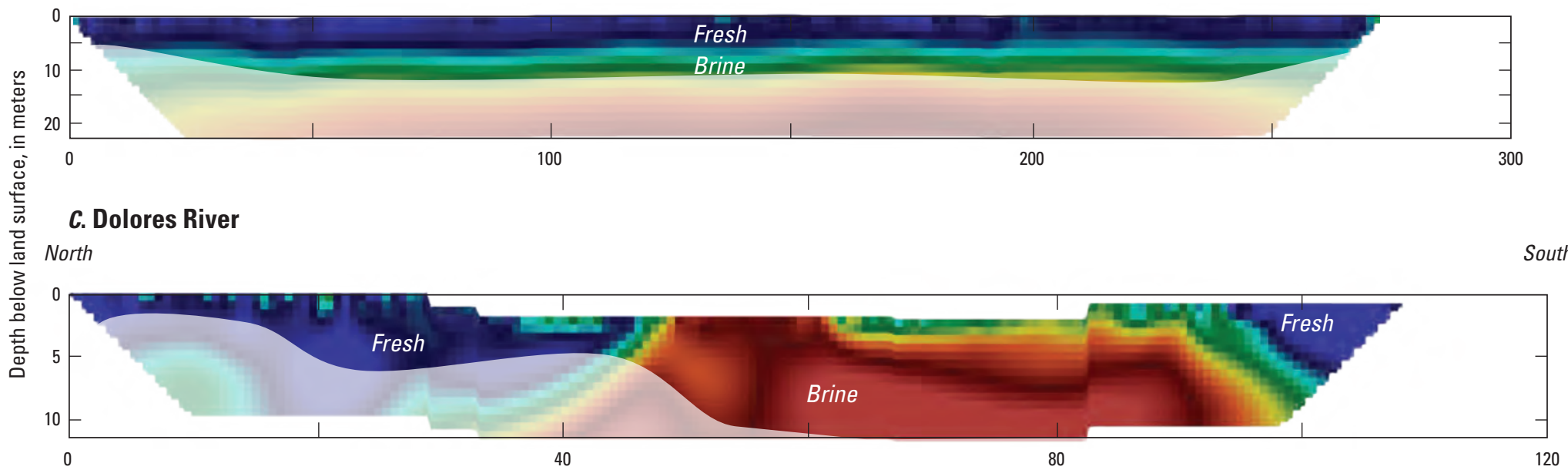

\section{Dolores River}

North

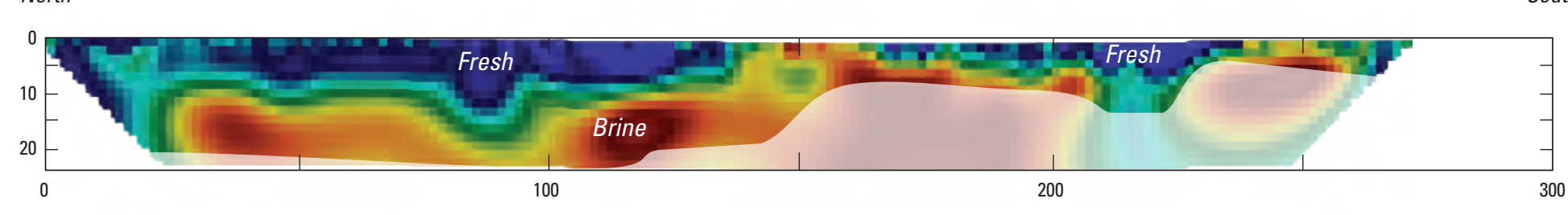

Survey distance, in meters

\section{EXPLANATION}

Bulk electrical conductivity, in microsiemens per

100,000

10,000

10,000

1,000

100 (line a, electrode spacing $=2$ meters), $B$, survey parallel to river on the western river bank (line b, electrode spacing $=5$ meters), $C$, middle survey crossing the Dolores River (line $\mathrm{C}$, electrode spacing = 2 meters), and D, southernmost survey crossing the Dolores River (line d, electrode spacing = 5 meters), Paradox Valley, Colorado. Locations of the ERT survey lines are shown in fig. 1. Areas beneath the computed depth of investigation are semi-transparent. 

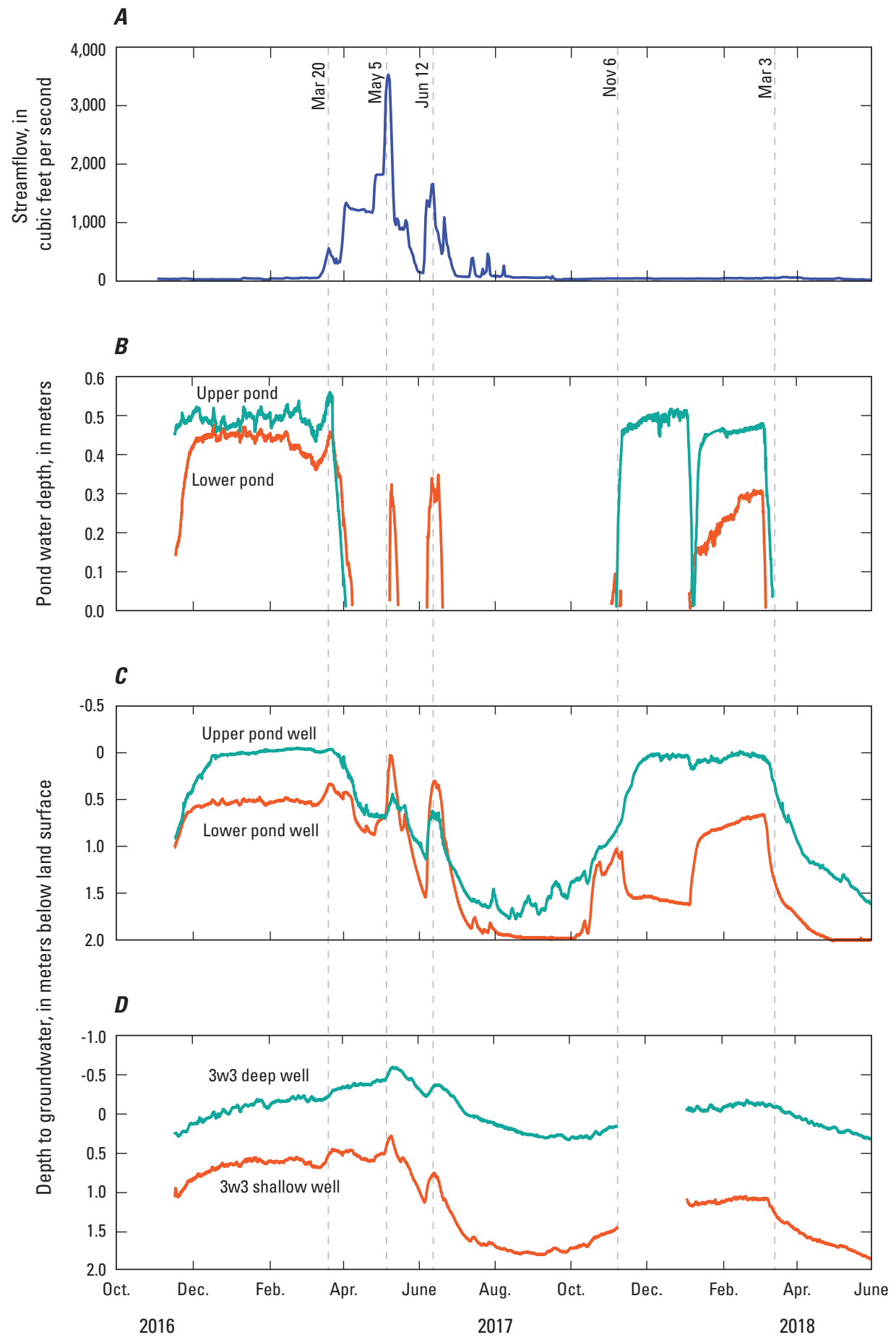

Figure 7. A, Streamflow for Dolores River near Bedrock (station 09171100); $B$, water depth in the wildlife ponds; $C$, depth to groundwater in upper and lower pond wells; and $D$, depth to groundwater in shallow and deep 3W3 wells, Paradox Valley, Colorado, during November 2016 through May 2018. 
pond well is much closer to the river than the upper pond well (fig. 2). Groundwater levels in the lower pond well remained low through late summer 2017 before rising in early October 2017. During this same period, both ponds remained dry, and streamflow was stable, indicating the rising groundwater levels in October 2017 may have resulted from increased streamflow in West Paradox Creek or lower rates of evapotranspiration, or both. Around the time the upper pond started to fill on November 6, 2017, the groundwater level dropped at the lower pond well and rose at the upper pond well, perhaps reflecting redirection of surface water into the upper pond. The groundwater level in the lower pond well rose again in early January 2018 while the lower pond was filled. Groundwater levels in both wells dropped quickly after the ponds dried up in March 2018.

Groundwater levels in the nested wells at 3W3 (fig. 2) showed a seasonal pattern similar to that of the pond wells, but the response was more muted, likely reflecting a slower response at greater depths in the aquifer (fig. $7 D$ ). A data-logger battery failure prevented water-level recording during a portion of the second winter. The gradual increase in groundwater level through the winter months may be in response to decreased evapotranspiration and increased recharge due to infiltration from West Paradox Creek and the upper pond. The highest groundwater levels (smallest depth to groundwater) followed the May 5, 2017, streamflow release, and a second rise followed the June 12,2017 , release. Groundwater levels gradually declined through the summer, likely reflecting increased evapotranspiration and upstream diversion of West Paradox Creek for irrigation. The groundwater level in the deeper well was higher than that in the shallow well during all months of the year, indicating upward groundwater flow at this location. Groundwater levels during the second winter were lower than during the first winter, perhaps reflecting drier conditions in 2018.

\section{Salt Loads in the River}

The daily TDS load in tons per day at the two USGS streamflow-gaging stations on the Dolores River and daily net salt gain for October 2016 through May 2018 are shown in figure 8 . Beginning in October 2016, the net salt gain increased steadily through the fall and winter months, reaching a maximum at the end of January 2017. The net salt gain primarily resulted from SC increases at the downstream site. Release of water from $\mathrm{McPhee}$ Dam remained at about $40 \mathrm{ft}^{3} / \mathrm{s}$ during winter (Colorado Division of Water Resources, 2019), and the SC at the upstream site was nearly constant through the winter (U.S. Geological Survey, 2019). Net salt gain dropped off dramatically starting on March 1, 2017, as flows in the river began to increase, and was essentially zero during the peak flow period in early May (fig. 7A). The negative values of salt gain during short-duration streamflow events in August likely resulted from time lags of peak runoff measurements between the upstream and downstream sites. Following these summer events, salt gain increased again starting in the fall of 2017 and peaked in early spring of 2018. Net salt gain started dropping on March 4, 2018, with the lowest gain on May 4 (fig. 8). In contrast to net salt gain in 2017, net salt gain remained well above zero during the spring months, reflecting the low-flow conditions of the river during the second year of monitoring.

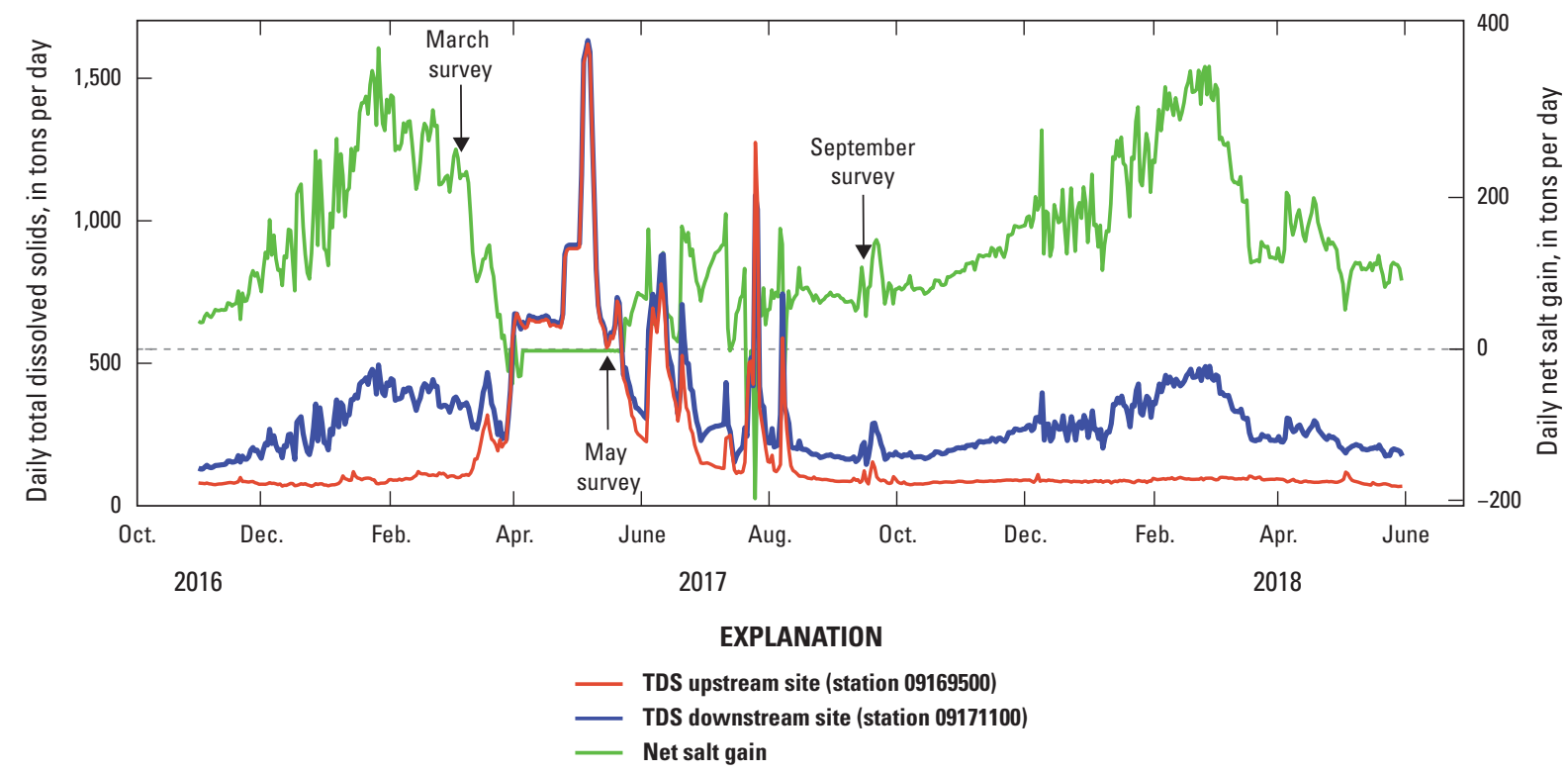

Figure 8. Daily total dissolved solids (TDS) load at two U.S. Geological Survey streamflow-gaging stations (stations 09169500 and 09171100 ) on the Dolores River and daily net salt gain to the river from the Paradox Valley, Colorado, October 2016 through May 2018. Arrows indicate dates of the geophysical surveys. 


\section{Controls on Brine Discharge to the Dolores River}

\section{Spatial and Temporal Extent of Brine Interpreted from Geophysical Surveys}

Although the extent of brine had been previously mapped (Ball and others, 2015; Bureau of Reclamation, 1978), geophysical surveys conducted as part of this study help to refine the extent and changes through time. Airborne electromagnetic (AEM) surveys (Ball and others, 2015) mapped the spatial extent of the brine in October 2011 at the scale of the valley floor. The AEM surveys indicate that the brine is closest to the surface directly under the river (fig. $9 A$ and $B$ ). Away from the river, the pattern is asymmetrical with less conductive materials on the northwest side. This asymmetry likely reflects the thickness of the freshwater lens in the alluvial aquifer, which is thicker northwest of the river because of groundwater recharge from West Paradox Creek and irrigated fields (fig. 1). Depth slices of inverted bulk EC from the March 2017 FDEM surveys conducted by this study are shown along with results from the 2015 AEM surveys in figure 9. The AEM surveys are centered at $1.5 \mathrm{~m}$ and $5.0 \mathrm{~m}$ below land surface, and FDEM surveys are at $1.38 \mathrm{~m}$ below land surface and $5.17 \mathrm{~m}$ below land surface. There is generally good agreement between the two methods, with a low conductivity (less than $1,000 \mu \mathrm{S} / \mathrm{cm}$ ) anomaly northwest of the Dolores River down to at least 5-m depth, indicative of a thicker freshwater lens in this region.

River-based geophysical surveys reveal spatial and temporal EC variations below the Dolores River that likely result from changes in groundwater salinity. For example, the low EC region from 0 to 2,000 $\mathrm{m}$ along the Dolores River, visible in the March and September FDEM and CRP surveys (fig. $4 A, C$; fig. $5 A, C$ ), probably indicates fresher groundwater beneath this reach of the river than farther downstream. The 2,000-m to 4,000-m reach shows a high $\mathrm{EC}$ anomaly, which is likely the freshwater-brine interface rising in elevation. Higher salinity groundwater apparently begins to discharge to the river near river distance $4,000 \mathrm{~m}$, as indicated by rising specific conductance measured in the river (fig. 3).

There are several low EC anomalies between the 5- and 10-m depth in the CRP data (fig. 5) in the 4,000-m to 8,000-m reach of the Dolores River. Inversion results from a repeat CRP survey in May 2017 along the 6,800-m to 9,000-m reach reproduced these features. The anomalies may represent regions of freshwater or less electrically conductive lithologies. One possibility is that interception of brine by the PVU production wells could be responsible for these low EC anomalies. In some cases, the low EC anomalies occurred in the approximate area of the production wells (within $100 \mathrm{~m}$ of a well, if the position of the well were projected to the river), but the low EC anomalies were not consistent or unique with the positions of the wells. For example, production well 9E (near river distance 6,500 m) (fig.1) is within 10 meters of the river and showed no strong association with the overall pattern in waterborne FDEM data.

One particularly large feature, spanning approximately $150 \mathrm{~m}$, is the low EC anomaly visible in both the CRP data and the FDEM data at approximately $6,800 \mathrm{~m}$. This anomaly possibly represents a larger zone of freshwater below the river, although the river SC data (fig. 3) do not show any substantial decrease at this location (as might be expected if freshwater were discharging to the river at this location). However, it is possible that the river SC measurements did not directly intersect the mixing zone of freshwater and saline water, which would likely be focused on the western bank of the river; therefore, the effect of freshwater discharge to the river was not detected as the boat was mainly in the center of the channel. Though it is also possible that this region represents an area of recharge, where sediments are replenished with fresh surface water during periods of high flow and with more saline surface water during periods of low flow, this was deemed unlikely given the apparent connection between freshwater zones on the west side of the river and the freshwater zone beneath the river seen in the ERT data (fig. $6 A$ ). Furthermore, groundwater seeps and relatively concentrated vegetation cover were observed on the west side of the river in this region, again supporting that fresher groundwater primarily discharges along this reach of the river.

Differences in bulk EC from FDEM inversions between the seasons are shown in figure 10. Because of high flows in May relative to March, May-March EC differences (fig. 10A) likely result from changes in water levels and river SC. March and September had similar streamflows and water levels, and the September-March EC profile (fig. 10B) exhibits an abrupt change from decreased EC south of the bend in the river to increased EC north of the bend (fig. 1), which coincides with the location of the observed EC anomaly (figs. 4 and 5).

The inverted March ERT results (fig. 6) indicate relatively low bulk EC in the upper $10 \mathrm{~m}$ on the west side of the river, which likely corresponds to the relatively thick freshwater lens interpreted from the AEM and FDEM data (fig. 9) northwest of the river. This interpreted freshwater lens is thinner (less than $5 \mathrm{~m}$ ) on the east side of the river than on the west side. The deeper more conductive layer likely results from the presence of brine in the aquifer. Because lateral heterogeneity in EC may result from lithologic variations, additional analysis (for example coring or other geophysical methods, or both) would be needed to discriminate lithologic variations from changes in groundwater salinity. The northernmost ERT profile (figs. 1, 6A), corresponding to the zone where a low EC anomaly at the river bend $(6,800 \mathrm{~m})$ is observed in the FDEM and CRP data (figs. 4 and 5), resolves a low EC zone below the interpreted brine layer, although this interpreted feature is partially 
A

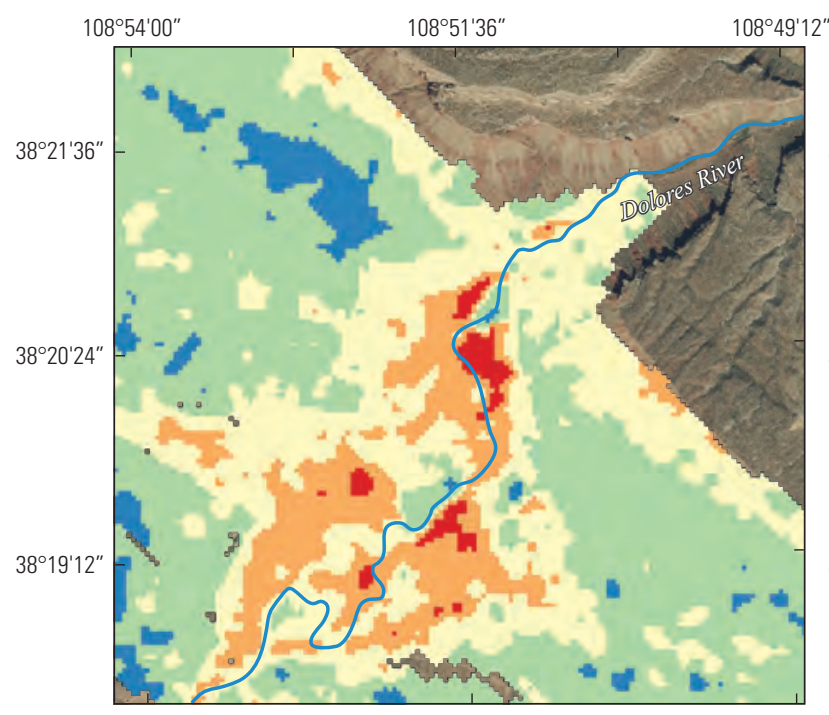

C

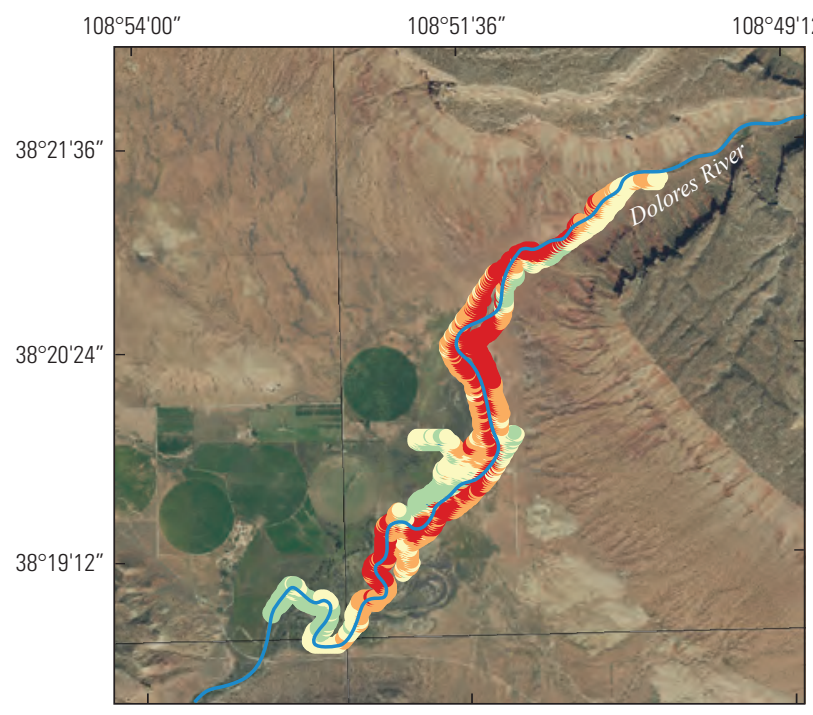

B

$108^{\circ} 54^{\prime} 00^{\prime \prime} \quad 108^{\circ} 51^{\prime} 36^{\prime \prime} \quad 108^{\circ} 49^{\prime} 12^{\prime \prime}$

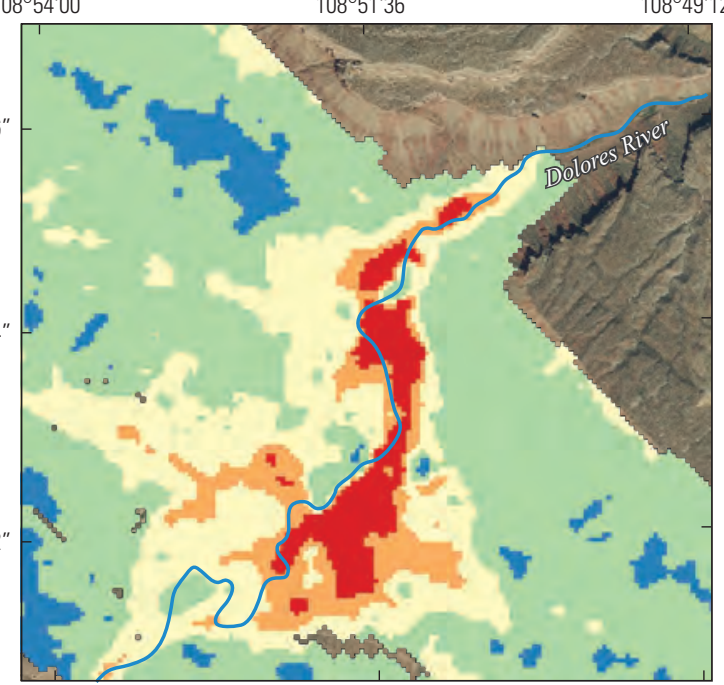

D

$108^{\circ} 54^{\prime} 00^{\prime \prime} \quad 108^{\circ} 51^{\prime} 36^{\prime \prime} \quad 108^{\circ} 49^{\prime} 12^{\prime \prime}$

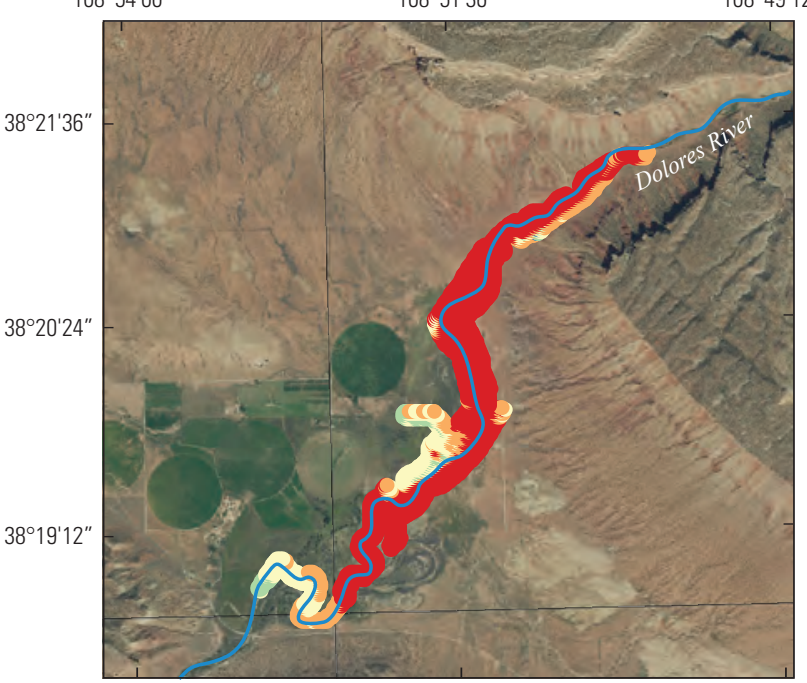

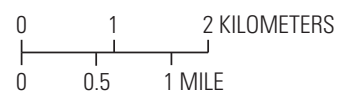

EXPLANATION

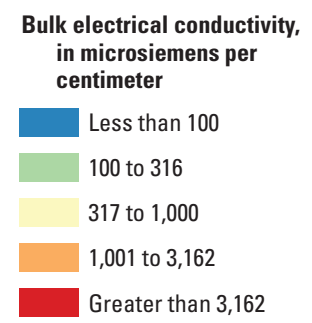

Figure 9. Interpolated depth slices of electrical conductivity (EC) from land- and river-based frequency domain electromagnetic induction (FDEM) inversions in 2017 and aerial electromagnetic (AEM) inversion results from Ball and others (2015): $A$, AEM EC depth slice centered at 1.5 meter below land surface, $B$, AEM EC depth slice centered at 5.0 meter below land surface, $C$, FDEM EC depth slice from 1.38 meter below land surface, and $D$, FDEM EC depth slice from 5.17 meter below land surface. 
beneath the computed depth of investigation. This may indicate a spring discharging to the surface on the west side of the river, though additional data would be needed to confirm this interpretation.

Overall, the river-based geophysical surveys made during low-flow conditions indicated a high electrical conductivity anomaly under the river between 4,000 and $8,700 \mathrm{~m}$, interpreted as the reach where brine-rich groundwater discharges to the river. The higher river salt load during this time indicates enhanced brine discharge is occurring in this reach (fig. 8). The CRP data (fig. 5) indicate that brine discharge may be discontinuous through several separate zones. During low-flow conditions, the freshwater lens is approximately $10 \mathrm{~m}$ thick on the western bank of the river and less than $5 \mathrm{~m}$ on the eastern bank. A large low EC anomaly at river distance $6,800 \mathrm{~m}$, near a bend in the Dolores River, was observed in all surveys and may represent a freshwater discharge zone or a losing reach of the river. During high-flow conditions (May), which generally occur in the spring, the brine interface is at a deeper level below the streambed interface than during low-flow conditions, and brine discharge is reduced to a minimum (fig. 8).

\section{Effect of Ponds on Salt Loading to the River}

One of the questions addressed by this study is, What effect does the filling and draining of the wildlife ponds have on net salt gain in the river? Casual observation indicates that pond filling appears to correspond to increased salt loading in the river. To address this question, the timing of water-level changes in the ponds and shallow groundwater were compared with changes in streamflow and net salt gain in the Dolores River over the 2 years of monitoring. In the first year (fig. 11A), the ponds were full, and water levels were stable between mid-December and early April. Over the same period, net salt gain in the river increased threefold, peaking in mid-February. The mid-winter peak and daily fluctuations in salt loads did not correlate with pond or shallow groundwater levels (fig. 7), which remained relatively stable, indicating other factors were more influential for controlling salt loads through the winter. This result is further supported by historical data (Mast, 2017), which show the pattern has not changed, and the magnitude of winter salt loads has not increased since the ponds were established in 2003. In fact, average daily net salt gain during winter months may have decreased slightly since 2003 (fig. 12). Following the mid-winter peak in 2017, salt loads in the river had already dropped by 75 percent by the time the ponds began to drain (fig. 11A), and the greatest drops in river salt coincided with increases in streamflow, indicating the river, rather than the ponds, was the main control on declining salt loads in spring.

During the second year of monitoring, net salt gain increased through the winter as in the previous year, but the increase appeared more pronounced in January and February 2018 than 2017 (fig. 11B). Note that although the timing of the increase appeared to coincide with filling of the lower pond, streamflow was estimated for most of December and January owing to icing, which could introduce some error into the calculated salt loads. Similar to the previous year, there were large daily fluctuations in salt load that did not correlate with water levels in the ponds (fig. 11B) or shallow groundwater (fig. 7C). The exception was a brief dip in salt load that occurred on January 8 when the water level briefly dropped in the upper pond and the lower pond began to fill. Although the cause of the sudden change in pond levels is unclear, this change corresponded to a period of wet weather and warmer nighttime temperatures (Western Regional Climate Center, 2019) that also caused a slight increase in streamflow (fig. 11B). In 2018, the first

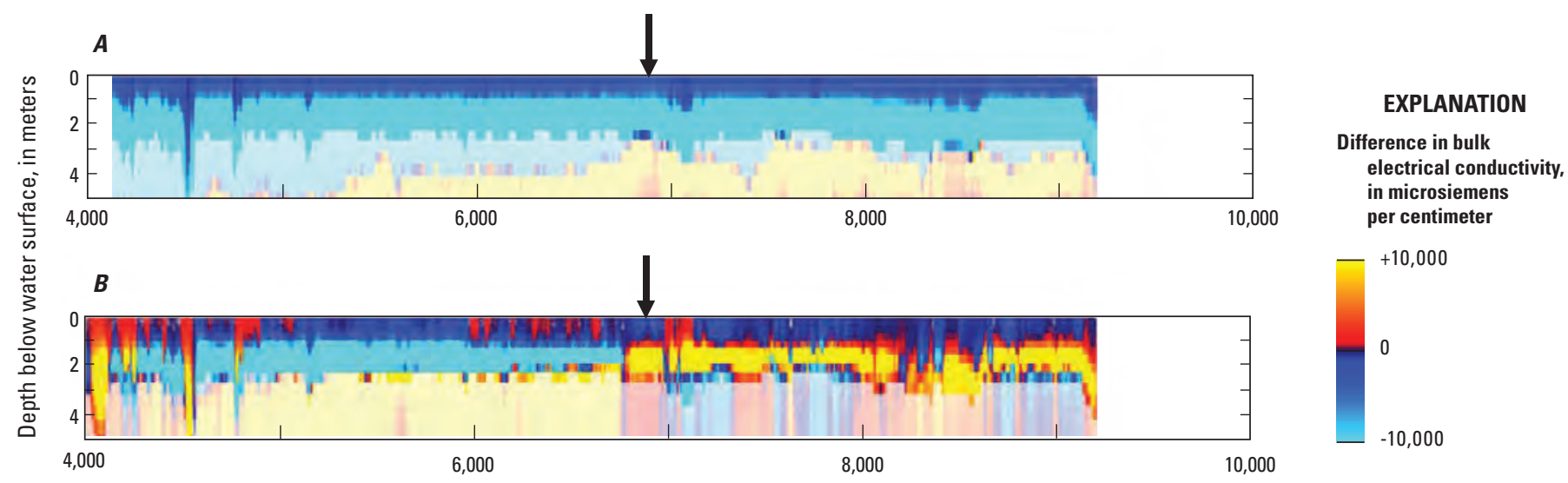

Figure 10. River-based time lapse frequency domain electromagnetic induction surveys along the Dolores River, Paradox Valley, Colorado: A, profile of May minus March bulk electrical conductivity and $B$, profile of September minus March bulk electrical conductivity. Arrow indicates the low electrical conductivity anomaly at the bend in the river. Areas beneath the computed depth of investigation are shown as semitransparent. Distance along river from figure 1. 

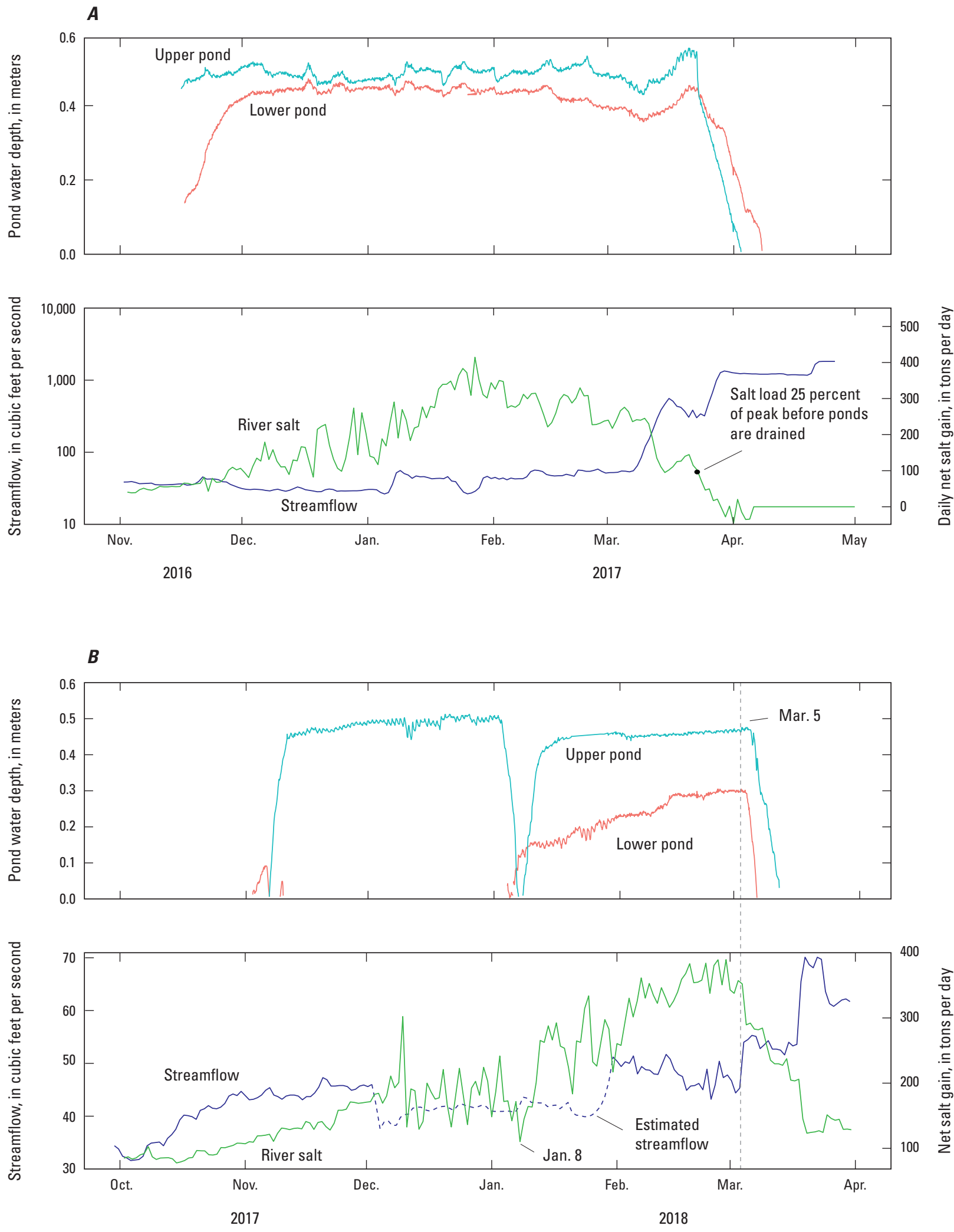

Figure 11. Pond water depth and daily streamflow at Dolores River near Bedrock, Paradox Valley, Colorado (station 09171100), and daily net salt gain in the river during $A$, winter and spring 2017 and $B$, winter and spring 2018. 
notable drop in river salt on March 5 was coincident with falling pond levels; however, streamflow also increased by $10 \mathrm{ft}^{3} / \mathrm{s}$ on the same day causing the $\mathrm{SC}$ of the river to decrease. Because the ponds drain by seepage into the shallow aquifer, the rate at which they drain (or fill) may be used to estimate their recharge rate to the aquifer. The recharge rate was estimated based on the total volume of water in the ponds and the average number of days to drain, which yielded a maximum rate of $0.4 \mathrm{ft}^{3} / \mathrm{s}$. Assuming this additional recharge eventually discharges into the river, the pond contribution to streamflow, which ranged from 40 to $70 \mathrm{ft}^{3} / \mathrm{s}$ during winter/spring 2018, appears to be minimal. Salt loading also depends on groundwater salinity, which was not measured as part of this study. However, the ERT survey, which was parallel to the west bank of the river and downgradient from the ponds (fig. 2), showed freshwater in the alluvial aquifer down to a depth of nearly 10 meters (fig. $6 B$ ). Considering the small rate of recharge and low salinity of shallow groundwater in the vicinity of the ponds, contributions of salt from the ponds via groundwater discharge into the river are likely insignificant.

Although the pond- and groundwater-level data over the 2-year study period did not establish that operation of the wildlife ponds had a measurable effect on salt loads in the Dolores River, the data did reveal there was active exchange of water between the river and adjacent alluvial aquifer. The effect of this exchange on brine discharge to the river can be seen by comparing monthly net salt gain between the 2 years of the study (fig. 13). During high flow in 2017, there was virtually no salt gain in April and May as the river crossed the valley. A potentiometric surface

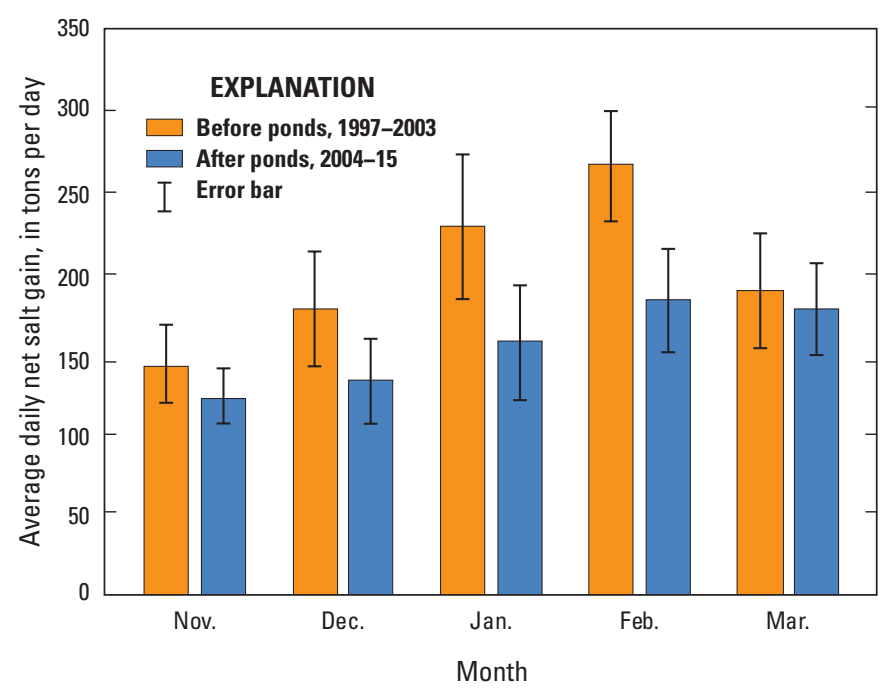

Figure 12. Average daily net salt gain in winter months in the Dolores River, Paradox Valley, Colorado, before and after the establishment of wildlife ponds on the west side of the river. The before period includes only years after the Paradox Valley Unit (PVU) went online, 1997-2003, and the after period is 2004-15. Error bars are the measurement uncertainty in the salt load determined by Mast (2017). constructed from groundwater-level elevations on the west side of the river during high flows in May (fig. 14) provided evidence that groundwater movement was away from the river thus recharging the alluvial aquifer with freshwater, which reduced brine discharge into the riverbed (Fritz and Arntzen, 2007). In contrast, river stage in April 2018 was not high enough for the flow gradient to reverse (fig. 14), and monthly net salt gains were substantially greater in April and May compared to those in 2017 (fig. 13). Outside the spring runoff season, streamflow was typically low and relatively constant, yet there were distinct changes in salt loading to the river, especially in winter, indicating the dynamics of surface water-groundwater interactions may change with season. In the next section of this report, these interactions are further explored by examining short-term fluctuations in the SC of the river and interannual variability in salt flux during the winter months.
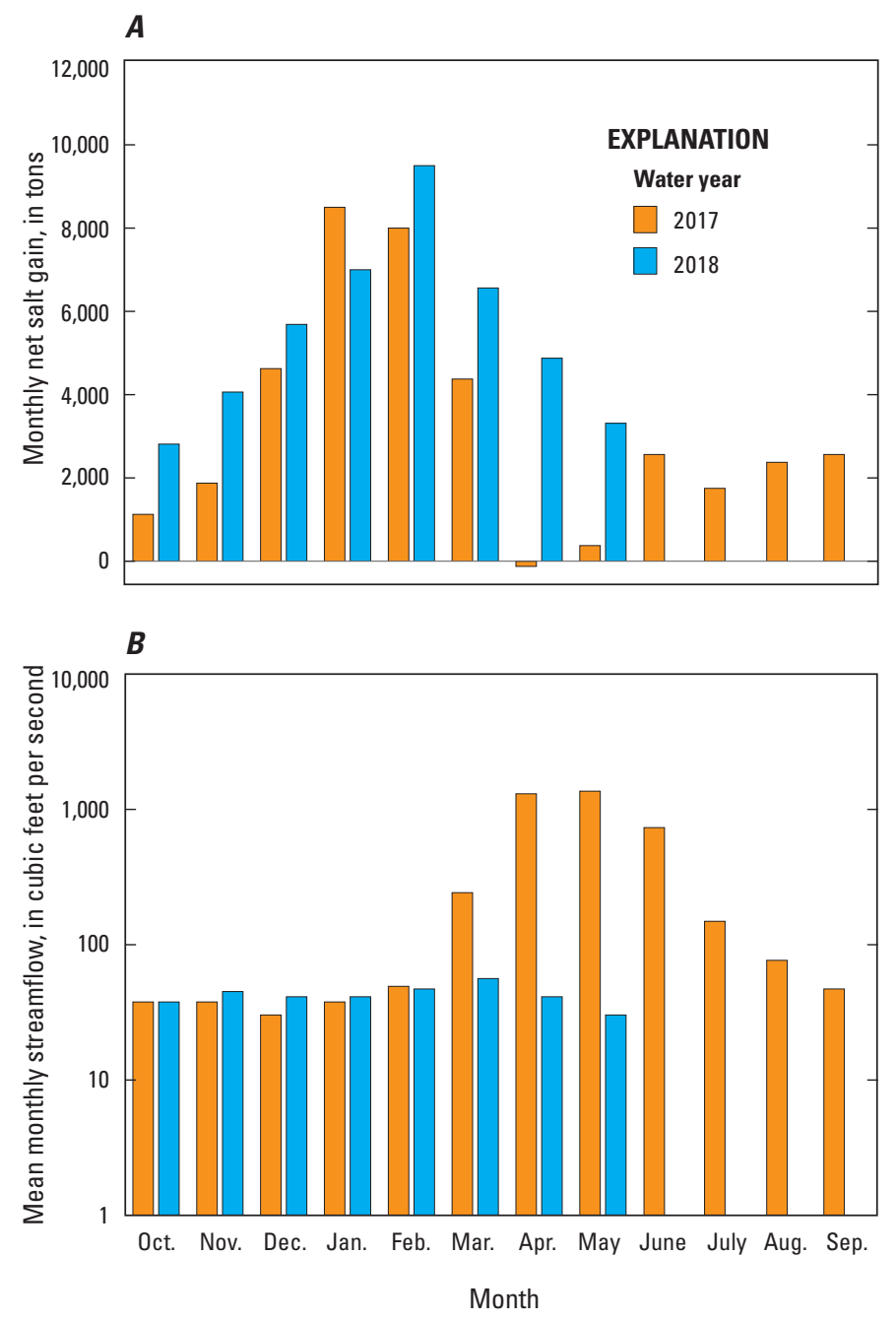

Figure 13. $A$, Monthly net salt gain and $B$, mean monthly streamflow at the Dolores River near Bedrock, Paradox Valley, Colorado (station 09171100), during water years (WY) 2017 and 2018. 
A. May 9, 2017 High River Stage

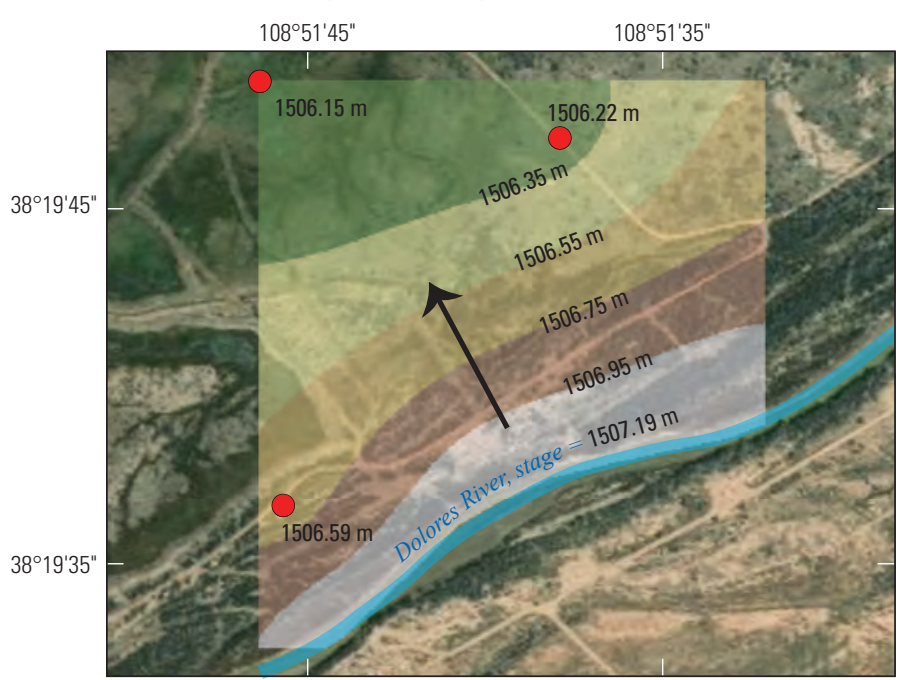

\section{B. April 15, 2018 Low River Stage}

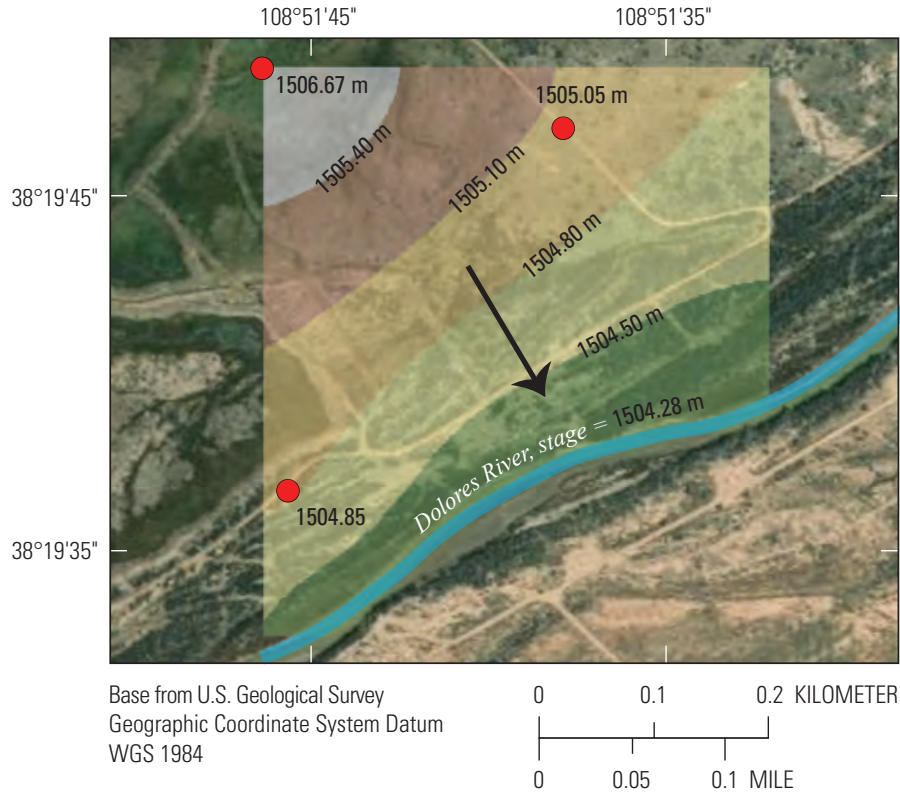

EXPLANATION

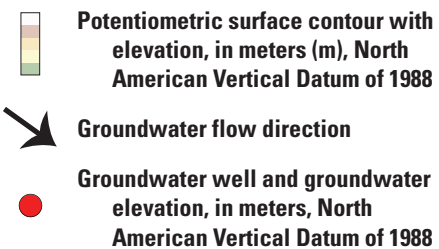

Figure 14. Potentiometric surface for the alluvial aquifer on the west side of the Dolores River, Paradox Valley, Colorado, under $A$, high-flow conditions on May 9, 2017, and $B$, low-flow conditions on April 15, 2018.

\section{Surface Water-Groundwater Interactions in Winter}

Brine discharge to the river was greatest during the winter months (fig. 13) with as much as 70 percent of the annual salt gain occurring during December through March. Increases in brine discharge in winter likely resulted from falling river stage, causing the freshwater-brine interface to move closer to the riverbed. Draining of the freshwater lens in the alluvial aquifer also may cause the brine interface to rise towards the river, although water levels in the monitoring wells rose during the winter, owing to recharge from ponds and West Paradox Creek (fig. 7), indicating that the freshwater lens northwest of the river was thicker in winter. However, these conditions may not be representative of the alluvial aquifer farther from West Paradox Creek, under the Dolores River, or beneath the southeast bank of the Dolores River.

During winter when river stage is lowest and the brine interface is presumably closest to the riverbed, there are periods lasting several days (see vertical grey bars in fig. 15) when the $\mathrm{SC}$ at the downstream site shows large diurnal changes (up to fivefold) in concentration (fig. 15A). This pattern also was observed at four upstream SC monitoring stations on the river operated by Reclamation (Andrew Nicholas, Reclamation, written commun., 2018; fig. 1), indicating that SC fluctuations are occurring in the Dolores River and are not an instrumental artifact (such as winter icing). The fluctuations in SC appear to correlate with periods of diurnal variation in gage height (fig. 15B). Although icing at the streamflow-gaging station can affect river gage-height measurements, a similar pattern was observed at the upstream site that was phase shifted 3-4 hours earlier (the approximate travel time between streamflow-gaging stations based on time lags during runoff events [see Mast, 2017]), indicating the stage fluctuations are real and not primarily caused by icing-induced measurement error. The stage fluctuations occurred when nighttime air temperatures dropped to levels well below freezing (fig. 15C) at the lower pond, indicating that freezing and melting of ice along the river channel may explain the diurnal fluctuations in river stage. Because the diurnal pattern also was observed at the upstream site, stage fluctuations may be generated by melting and freezing along the canyon upstream from Bedrock, Colorado, as well as along the floor of Paradox Valley.

These periods of diurnal fluctuation in stage and SC are important because they appear to be associated with periods of increased salt flux to the Dolores River, which is illustrated in figure 16, during a period of transitioning air temperatures in early winter 2018 at the downstream site (U.S. Geological Survey, 2019). Data presented in figure 16 are from water year 2019 and are included to demonstrate the relation between salt load and stage. In late October and early November 2018, salt load remained relatively constant while the stage was stable. Once stage fluctuations commenced, presumably in response to falling air temperatures (around November 13), the salt load increased by a factor of nearly 4 over the next 6 weeks. The increase in salt load during this period cannot be explained 

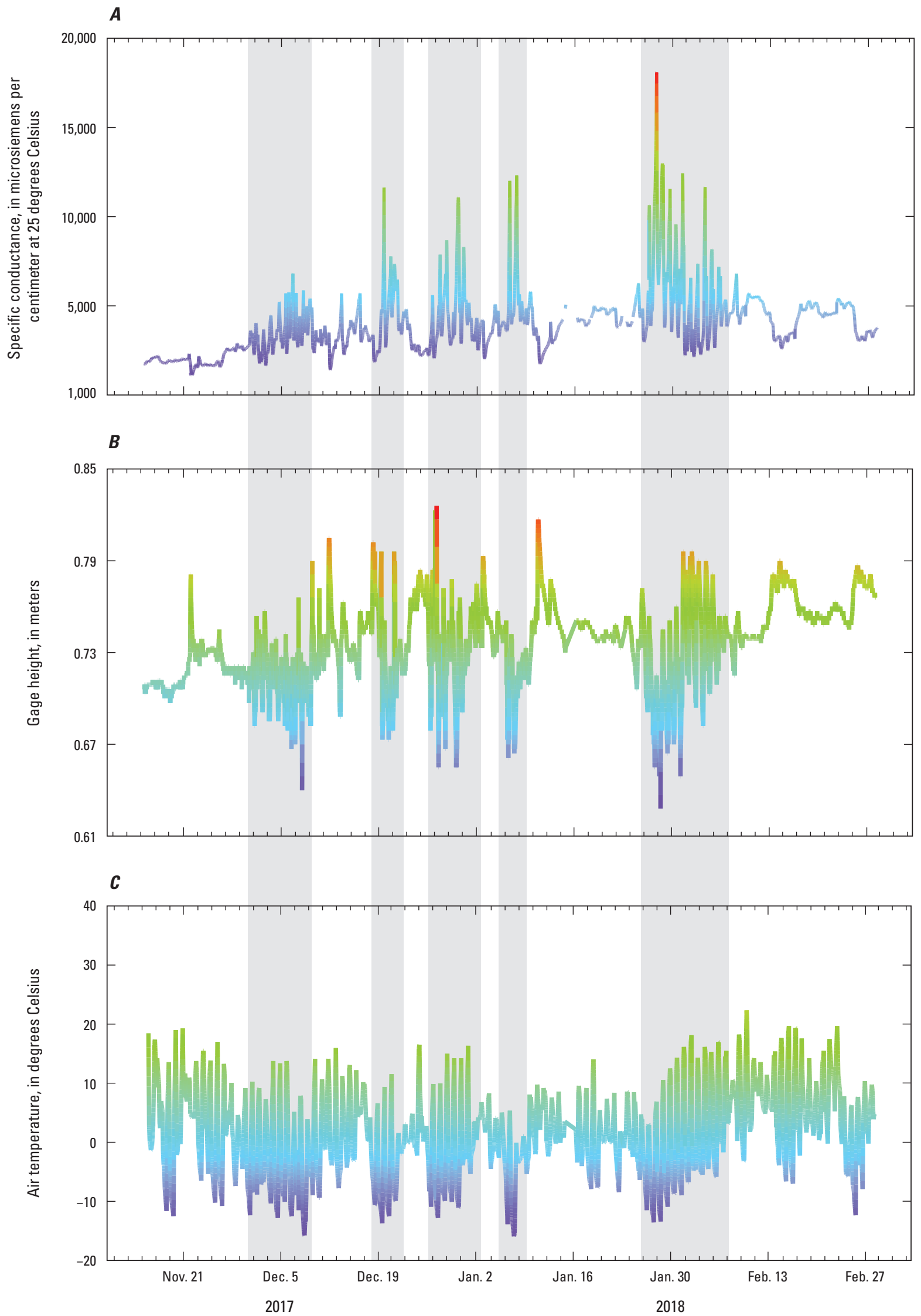

Figure 15. Winter diurnal fluctuations in $A$, specific conductance and $B$, gage height of the Dolores River near Bedrock, Paradox Valley, Colorado (station 09171100), and $C$, air temperature at the lower pond during winter 2017-18. Line color on each graph is scaled to the y-axis. 
solely by a decline in river stage because, although there were low daily minimums, the average daily stage actually increased slightly by the end of December 2018. A possible explanation is that the diurnal stage fluctuations promote flow of water from the stream into the underlying streambed sediments or hyporheic zone (Loheide and Lundquist, 2009). Higher stream stage results in flow of fresh river water into the hyporheic zone where it mixes with brine upwelling from the alluvial aquifer. As the stage drops, the saltier water in this mixing zone flows back into the river, thereby increasing salt flux into the river. Similar mechanisms of surface-water pumping into the hyporheic zone have been described for snowmelt-dominated systems (Loheide and Lundquist, 2009 and in tidal environments (Santos and others, 2012). Another feature of these diurnal cycles is that the peak in SC of each cycle lagged behind the minimum stage by $2-3$ hours. The hydraulic diffusivity of the shallow alluvial aquifer, which controls how fast a change in hydraulic head propagates through the aquifer (Arntzen and others, 2006), could explain the observed time lag between the minimum river stage and the subsequent discharge of salt-enriched groundwater from the hyporheic zone. The observed lag between river stage and SC is apparent only when flows in the river are low and when diurnal temperature changes correlate with changes in river stage, such as might result from melting and freezing along the river corridor upstream from and across the Paradox Valley.

Although the diurnal stage fluctuations appear to play a role in increasing salt flux through the winter, there were substantial inter-annual differences in winter salt gain that may not be solely explained by this mechanism. Based on data from Mast (2017) for 1997-2015 (the period after PVU started operation), net salt gain for November through March ranged from 36 tons (32.7 metric tons) per day in 2014 to 408 tons (370 metric tons) per day in 1999. A comparison of winter salt gain to climatic and hydrologic conditions revealed that net winter salt gain was positively correlated with peak streamflow during the previous year's spring runoff period (fig. 17). Even though brine discharge is suppressed during high-flow events, such as observed in 2017, the influx of freshwater into the alluvial aquifer during high flow appears to eventually (within 1 year) increase brine discharge to the river. A possible explanation for this observation is that increased groundwater levels during spring runoff may drive groundwater downward into deeper and saltier regions of the aquifer system. The decreasing depth to groundwater in $3 \mathrm{~W} 3$ deep well (fig. 7), which is completed in the brine-rich caprock, during peak streamflow in spring 2017 indicates that saltier regions in some parts of the aquifer did respond to changing river flows. When groundwater levels eventually drop, upward flow from these saltier regions towards the river may recharge the brine layer in the alluvial aquifer. Because the brine layer is closest to the river during winter, this may explain the lag between peak runoff and increased salt flux. Another possible explanation is that enhanced recharge during peak-flow periods leaches previously accumulated salts from the unsaturated zone to the water table. The salts then flow toward and eventually discharge into the river, and the lag reflects the travel time for groundwater flow from the area of leaching to the river. The relative importance of these two mechanisms is uncertain; seasonal measurements of groundwater salinity could help to improve understanding of enhanced salt dissolution following high-flow conditions in the river.

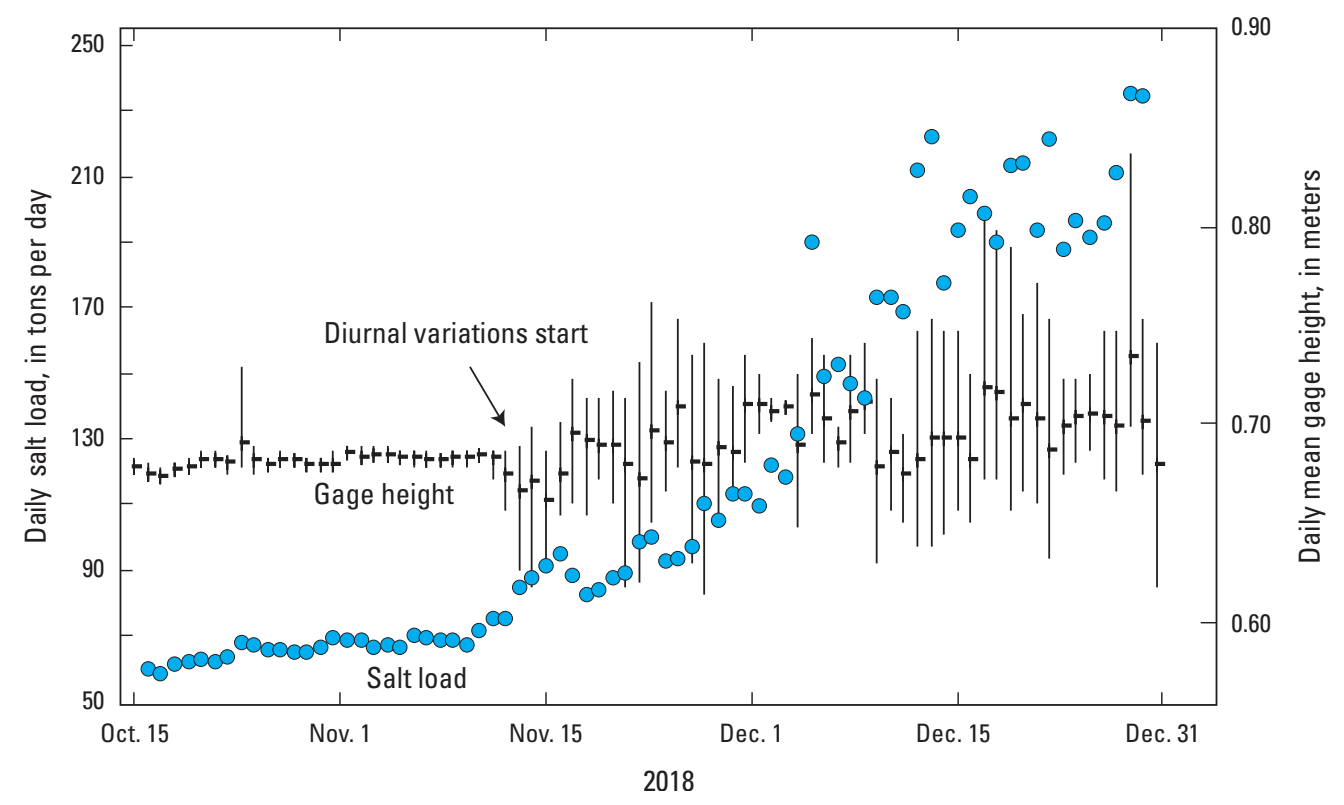

Figure 16. Daily salt load and mean daily gage height in the Dolores River near Bedrock, Paradox Valley, Colorado (station 09171100), for early winter 2018 (water year 2019). Vertical bars for stage represent daily minimum and maximum values (U.S. Geological Survey, 2019). 


\section{Conceptual Model of Brine Discharge to the Dolores River}

Based on the hydrologic and geophysical data analyzed for this study and results from previous studies, a conceptual model of brine discharge to the Dolores River in Paradox Valley was developed at three scales: (1) a regional scale that includes deep groundwater flow under the valley, (2) an intermediate scale for lateral flow between the river and the adjacent alluvial aquifer, and (3) a fine scale of interactions between the river and underlying bed sediments.

At the regional scale, deep groundwater flow enables dissolution of salt in the Paradox Formation and movement of the resulting brine through the base of the alluvial aquifer to discharge into the river (Konikow and Bedinger, 1978). Geophysical measurements have mapped the extent and depth of the brine in the center of the valley (Ball and others, 2015, see "Spatial and Temporal Extent of Brine Interpreted from Geophysical Surveys" section), but the mechanism that moves salt into the alluvial aquifer is not completely understood. Deeper groundwater is presumably recharged from higher elevations at the southeast and northwest ends of the valley and possibly from above the valley walls, then moves downward through fractures into the Paradox Formation where it dissolves salt and forms the brine. The elevation of recharge must be high enough to overcome the density of the brine and generate the hydraulic gradient for flow of brine through the fractured caprock at the top of the Paradox Formation into the base of the alluvial aquifer near the river (Konikow and Bredinger, 1978). Groundwater-age data indicate that brine flowing into the base of the alluvial aquifer is likely more than 10,000 years old (K. Watts, USGS, written commun., 2018), indicating that groundwater contacting the salt at the top of the Paradox Formation moves very slowly through the subsurface.

After brine upwells into the base of the alluvial aquifer, it moves towards and discharges into the river. Surface water-groundwater interactions at the scale of the alluvial aquifer control brine discharge to the river both seasonally and interannually. High stage in the river reversed the hydraulic gradient causing freshwater to move laterally into the adjacent alluvial aquifer (fig. 14), which depressed the brine interface below the riverbed, thus minimizing brine discharge. The geophysical surveys in May support this mechanism by revealing that the brine interface was depressed 1-2 meters beneath the river channel at a streamflow greater than $900 \mathrm{ft}^{3} / \mathrm{s}$ (fig. 4 and fig. 7A). Because the alluvial sediments are highly permeable, the flux of salt into the river changed almost immediately in response to fluctuations in river stage (fig. 11A).

Although a high river stage temporarily inhibits brine discharge to the river, high stage appears to eventually enhance brine discharge during the following winter low-flow period (fig. 17). Above average winter precipitation not only causes localized recharge of the alluvial aquifer in response to

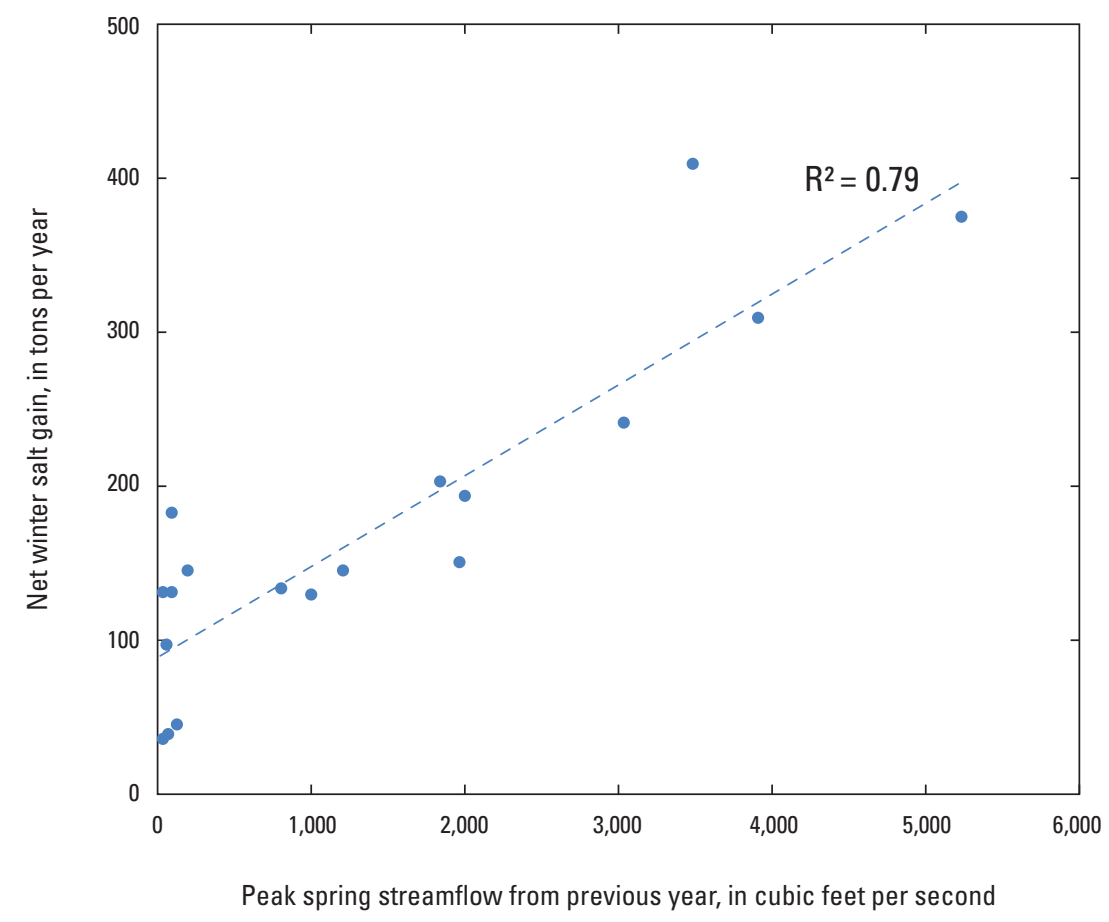

Figure 17. Net winter (November to March) salt gain in the Dolores River, Paradox Valley, Colorado, in relation to peak streamflow at Dolores near Bedrock (station 09171100) from the previous year's snowmelt for 1997-2015. Data from Mast, 2017 showing the regression line and the coefficient of determination $\left(R^{2}\right)$. 
elevated river stage, but also increases precipitation recharge to the groundwater system over a regional scale. Groundwater recharge following winters with greater precipitation also may be enhanced by high flows in West Paradox Creek and irrigation-return flows. These recharge mechanisms may subsequently increase the groundwater flux through the alluvial aquifer and eventually cause increased brine discharge to the river. Possible explanations include enhanced groundwater flow through saltier regions of the aquifer system and flushing of accumulated salts from the unsaturated zone, both of which could increase the salinity of groundwater in the alluvial aquifer.

At the finest scale, surface water-groundwater interactions along the channel affect salt flux during winter months. Diurnal fluctuations in river stage sometimes occur during winter in response to daily melt-freeze cycles, which drive temporary bank storage of freshwater (Rhodes and others, 2017) that exchanges with saltier pore water in the hyporheic zone. The exchange appears to increase the flux of salt from the sediment to the river in excess of what would occur if stage remained constant by as much as a factor of 4 during melt-freeze cycles (fig. 16). Although limited to the river channel, this fine-scale process appears to play an important role in enhancing salt flux to the river during winter months.

\section{Summary}

The Paradox Valley in southwestern Colorado is a collapsed anticline formed by movement of the salt-rich Paradox Formation at the core of the anticline. The salinity of the Dolores River, a tributary of the Colorado River, increases substantially as it crosses the valley because of discharge of brine-rich groundwater, which is derived from dissolution of salts in the underlying Paradox Formation. Although the brine is naturally occurring, it increases the salinity of the Colorado River, which is a major concern to downstream agricultural, municipal, and industrial water users. In 1997, the Paradox Valley Unit (PVU; nine production wells) began operating to reduce the salt load of the Dolores River. Although the PVU currently removes nearly 90,000 tons (about 81,650 metric tons) of salt annually, nearly 40,000 tons (about 36,290 metric tons) per year of salt is still exiting the valley in river flow. The U.S. Geological Survey in cooperation with the Bureau of Reclamation conducted a study to improve the characterization of processes controlling spatial and temporal variations in brine discharge to the Dolores River. This information is needed to inform decisions on water-management alternatives for reducing salt load in the Dolores River.

Geophysical surveys were conducted in 2017 during different seasons and hydrologic conditions, including low-flow conditions in March, high-flow conditions in May, and low-flow conditions in September. Three types of geophysical data were collected for this study: direct current electrical resistivity tomography, continuous resistivity profiling, and frequency domain electromagnetic induction. Each of these tools were used to estimate the electrical conductivity of earth materials as a proxy for groundwater salinity. Water levels in two wildlife ponds and three groundwater wells on the northwest side of the river were monitored from November 2016 through May 2018. Streamflow and specific conductance measurements made at two USGS streamflow-gaging stations on the Dolores River were used to estimate salt load in the river.

River-based geophysical surveys made during low-flow conditions indicated a high electrical conductivity anomaly under the river between 4,000 and $8,700 \mathrm{~m}$, interpreted as the reach where brine-rich groundwater discharges to the river. Under higher flow conditions in May, the high conductivity anomaly in the same reach was depressed below the riverbed by up to 2 meters $(\mathrm{m})$, and brine discharge was reduced to a minimum. Direct current electrical resistivity surveys made across the river showed that the freshwater lens overlying the brine is much thicker (up to $10 \mathrm{~m}$ ) on the west bank compared to the east bank (less than $5 \mathrm{~m}$ ). A large low conductivity anomaly near the river bend at river distance $6,800 \mathrm{~m}$ was observed in all surveys and may represent a freshwater discharge zone or a losing reach of the river.

Water-level monitoring conducted as part of this study indicated that filling and draining of the wildlife ponds on the west side of the river appeared to have a negligible effect on salt loads during the 2-year study. Groundwater monitoring did reveal there was active exchange of water between the river and the adjacent alluvial aquifer. When river stage was low, groundwater flowed towards the river, and discharge of brine to the river increased. When the river stage was high, the gradient was reversed, and fresh surface water recharged the alluvial aquifer, minimizing brine discharge. Most of the salt load to the river occurred during the winter months and appeared to be enhanced by diurnal stage fluctuations, which were caused by low nighttime air temperatures. However, inter-annual differences in the winter salt gain were not solely explained by this mechanism and were most strongly correlated with peak streamflow from the previous year's spring runoff. The relation between salt gain and peak streamflow indicates that recharge during wet winters causes increased groundwater flow that eventually increases brine discharge to the river.

Based on the hydrologic and geophysical data analyzed for this study and results from previous studies, a conceptual model of brine discharge to the Dolores River in Paradox Valley was developed at three scales: (1) a regional scale that includes deep groundwater flow under the valley, (2) an intermediate scale for lateral flow between the river and the adjacent alluvial aquifer, and (3) the fine scale of interactions between the river and underlying bed sediments. Groundwater at the regional scale drives dissolution of salt in the Paradox Formation and flow of brine into the base of the alluvial aquifer. Surface water-groundwater interactions at the intermediate scale of the alluvial aquifer control brine discharge to the river both seasonally and interannually. At the finest scale, diurnal fluctuations in river stage drive hyporheic exchange of freshwater with saltier pore water, which appears to enhance brine discharge to the river in winter. 


\section{References Cited}

Aarhus GeoSoftware, 2019, Aarhus Workbench web site, accessed May 2, 2019, at https://www.aarhusgeosoftware. $\mathrm{dk} /$ workbench-overview.

AGI, 2019, Advanced Geosciences Inc. electrical resistivity imaging instruments web page, accessed May 2, 2019, at https://www.agiusa.com.

Arntzen, E.V., Geist, D.R., and Dresel P.E., 2006, Effects of fluctuating river flow on groundwater/surface water mixing in the hyporheic zone of a regulated, large cobble bed river: River Research and Applications, v. 22, p. 937-946.

Auken, E., Christiansen A.V., Kirkegaard C., Fiandaca G., Schamper C., Behroozmand A.A., Binley A., Nielsen E., Effersø, F., Christensen N.B., Sørensen K., Foged N., and Vignoli G., 2015, An overview of a highly versatile forward and stable inverse algorithm for airborne, ground-based and borehole electromagnetic and electric data: Exploration Geophysics, v. 46, p. 223-235, accessed July, 1, 2018, at https://doi.org/10.1071/EG13097.

Ball, L.B., Bloss, B.R., Bedrosian, P.A., Grauch, V.J.S., and Smith, B.D., 2015, Airborne electromagnetic and magnetic survey data of the Paradox and San Luis Valleys, Colorado: U.S. Geological Survey Open-File Report 2015-1024, 19 p. [Also available at https://pubs.er.usgs.gov/publication/ ofr20151024.]

Binley, A., 2015, Tools and techniques: DC electrical methods, in Schubert, G., ed., Treatise on geophysics, (2d ed.): Cambridge, Mass., Elsevier Science, p. 233-259, accessed July 1, 2018, at https://doi.org/10.1016/B978-0-444-53802-4.00192-5.

Bureau of Reclamation, 1978, Colorado River Basin salinity control project—Paradox Valley Unit definite plan report, Appendix B-Hydrosalinity: Bureau of Reclamation, Upper Colorado Region, 173 p., accessed July 1, 2018, at https://www. usbr.gov/uc/wcao/progact/paradox/DPR1978-Appdx-B.pdf

Bureau of Reclamation, 2018, Colorado River Basin Salinity Control Program: Bureau of Reclamation, Upper Colorado Region web page, accessed July 1, 2018, at https://www. usbr.gov/uc/progact/salinity/index.html.

Bureau of Reclamation, 2019, Paradox Valley Unit Environmental Impact Statement web page: Bureau of Reclamation, accessed May 2, 2019, at https://www.usbr.gov/uc/wcao/ progact/paradox/.

Cater, F.W., 1970, Geology of the salt anticline region in southwestern Colorado, with a section on Stratigraphy, by Cater, F.W., and Craig, L.C.: U.S. Geological Survey Professional Paper 637, $80 \mathrm{p}$.

Christiansen, A.V., and Auken, E., 2012, A global measure for depth of investigation: Geophysics, v. 77, p. WB171-WB177.
Colorado Division of Water Resources, 2019, Colorado streamflow data web page, accessed May 2, 2019, at https:// www.dwr.state.co.us/SurfaceWater/default.aspx.

Cunningham, W.L., and Schalk, C.W., comps., 2011, Groundwater technical procedures of the U.S. Geological Survey: U.S. Geological Survey Techniques and Methods 1-A1, $151 \mathrm{p}$.

Day-Lewis, F.D., White, E.A., Belaval, M., Johnson, C.D., and Lane, J.W., 2006, Continuous resistivity profiling to delineate submarine ground-water discharge - examples and limitations: The Leading Edge, v. 25, no. 6, 724-728.

Freeman, L.A., Carpenter, M.C., Rosenberry, D.O., Rousseau, J.P., Unger, R., and McLean, J.C., 2004, Use of submersible pressure transducers in water-resources investigations: U.S. Geological Survey Techniques of Water-Resources Investigations, book 8, chap. A3, 52 p. [Also available at https:// doi.org/10.3133/twri08A3.]

Frischknecht, F.C., Labson, V.F., Spies, B.R., and Anderson, W.L., 1991, Profiling methods using small sources, in Nabighian, M.N., ed., Electromagnetic methods in applied geophysics: volume 2, application, parts A and B: Tulsa, Okla., Society of Exploration Geophysicists, 105-252 p.

Fritz, B.G., and Arntzen, E.V., 2007, Effect of rapidly changing river stage on uranium flux through the hyporheic zone: Groundwater, v. 45, p. 753-760, accessed April 1, 2019, at https://doi.org/10.1111/j.1745-6584.2007.00365.x.

Geophex Ltd., 2019, Hand-held GEM-2 Ski web site, accessed May 2, 2019, at http://www.geophex.com/Product_GEM2_ handheld.htm.

Konikow, L.F., and Bedinger, M.S., 1978, Evaluation of hydrogeologic aspects of proposed salinity control in Paradox Valley, Colorado: U.S. Geological Survey Open-File Report 78-27, 56 p. [Also available at https://pubs.usgs.gov/ of/1978/0027/report.pdf.]

Lancaster University, 2019, R2 Freeware version $3.3 \mathrm{web}$ page, accessed May 2, 2019, at http://www.es.lancs.ac.uk/ people/amb/Freeware/R2/R2.htm.

Loheide S.P., and Lundquist, J.D., 2009, Snowmelt induced diel fluxes through the hyporheic zone: Water Resources Research, v. 45, no 7, April 1, 2019, at https://doi.org/ 10.1029/2008WR007329.

Mast, M.A., 2017, Estimation of salt loads for the Dolores River in the Paradox Valley, Colorado, 1980-2015: U.S. Geological Survey Scientific Investigations Report 2017-5059, 20 p. [Also available at https://doi.org/10.3133/ sir20175059.] 
Mast, M.A, Terry, N., Henneberg, M., and White, E., 2019, Continuous resistivity profiling, direct current resistivity survey, and electromagnetic survey data collected in and adjacent to the Dolores River in the Paradox Valley, Colorado, 2017: U.S. Geological Survey data release, https://doi.org/ 10.5066/F77080NB.

National Resources Conservation Service, 2019, Snow Telemetry (SNOTEL) web page, accessed May 2, 2019, at https:// www.wcc.nrcs.usda.gov/snow/.

Oldenburg, D.W., and Li, Y., 1999, Estimating depth of investigation in dc resistivity and IP surveys: Geophysics, v. 64, no. 2 , p. $403-416$.

Onset, 2019, Onset HOBOware software web page, accessed June 6, 2019, at https://www.onsetcomp.com/products/ software/hoboware.

Rhodes, K.A., Proffitt, T., Rowley, T., Knappett, P., Montiel, D., Dimova, N., Tebo, D., and Miller, G., 2017, The importance of bank storage in supplying baseflow to rivers flowing through compartmentalized, alluvial aquifers: Water Resources Research, v. 53, iss. 12, p. 10539-10557, accessed May, 1, 2019, at https://doi.org/10.1002/2017wr021619.

Rydlund, P.H., Jr., and Densmore, B.K., 2012, Methods of practice and guidelines for using survey-grade global navigation satellite systems (GNSS) to establish vertical datum in the United States Geological Survey: U.S. Geological Survey Techniques and Methods, book 11, chap. D1, 102 p. [Also available at http://pubs.usgs.gov/tm/11d1/.]

Colorado Water Science Center

Publishing support provided by the Science Publishing Network, Denver Publishing Service Center

For more information concerning the research in this report, contact the Director, USGS Colorado Water Science Center

Box 25046, Mail Stop 415

Denver, CO 80225

(303) 236-4882

Or visit the Colorado Water Science Center website at

https://www.usgs.gov/centers/co-water
U.S. Geological Survey, 2019, USGS 09169500 Dolores River at Bedrock, CO, in USGS water data for the Nation: U.S. Geological Survey National Water Information System database, accessed May 2, 2019, at https://doi.org/10.5066/F7P55KJN. [Site information directly accessible at https://waterdata. usgs.gov/co/nwis/uv/?site_no=09169500\&PARAmeter_ $\mathrm{cd}=00065,00060$ ]

Watts, K.R., 2000, Effects of the Paradox Valley Unit on dissolved solids, sodium, and chloride in the Dolores River near Bedrock, Colorado, water years 1988-98: U.S. Geological Survey Water-Resources Investigations Report 00-4011, 8 p.

Western Regional Climate Center, 2019, Climate data for Nucla RAWS station web page, accessed May 2, 2019, at https://raws.dri.edu/cgi-bin/rawMAIN.pl?coCNUC.

Santos, I.R., Eyre, B.D., and Huette, M., 2012, The driving forces of pore water and groundwater flow in permeable coastal sediments - A review: Estuarine, Coastal and Shelf Science, v. 98, p. 1-15.

YSI, 2019, Water quality sampling and monitoring meters and instruments web page, accessed May 2, 2019, at https:// www.ysi.com/. 

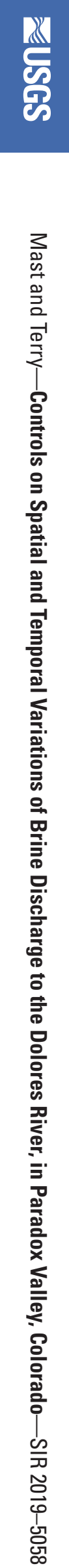